\title{
A Tool to Analyze, Ideate and Develop Circular Innovation Ecosystems
}

\author{
Jan Konietzko ${ }^{1, *}$, Nancy Bocken ${ }^{1,2}$ and Erik Jan Hultink ${ }^{1}$ \\ 1 Faculty of Industrial Design Engineering, Delft University of Technology, 2628 CE Delft, The Netherlands; \\ nancy.bocken@iiiee.lu.se (N.B.); H.J.Hultink@tudelft.nl (E.J.H.) \\ 2 The International Institute for Industrial Environmental Economics, Lund University, Tegnérplatsen 4, \\ 22100 Lund, Sweden \\ * Correspondence: j.c.konietzko@tudelft.nl; Tel.: +49-157-56013100
}

Received: 10 December 2019; Accepted: 31 December 2019; Published: 5 January 2020

check for updates

\begin{abstract}
The circular economy may help firms to maximize the value of their material resources and minimize the overall resource use, waste, pollution and emissions of their business activities. Implementing a circular economy program requires radical changes in product, business model and ecosystem innovation. Most research on circular oriented innovation takes a product or business model perspective. Few publications have explored how to innovate in ecosystems: how a group of loosely coupled organizations can change how they interact with each other to achieve a collective outcome. This study proposes the Circularity Deck: a card deck-based tool that can help firms to analyze, ideate and develop the circularity potential of their innovation ecosystems. The tool is based on a literature review of circular oriented innovation principles, and of practical examples that show how these principles have been applied. The principles are organized according to the intended circular strategy outcome that they pursue (i.e., narrow, slow, close, regenerate and inform material and energy flows), and the extent of the innovation perspective that is needed to operationalize a principle (i.e., product, business model, or ecosystem innovation). This review and categorization process first produced a novel analysis of the circular economy innovation landscape, using an ecosystem perspective. Second, these results served to develop the Circularity Deck, which was further developed and tested for ease of use and perceived usefulness in 12 workshops with 136 participants from 62 different organizations. The Circularity Deck provides an approach for future research and practice to integrate new principles and examples that can help firms to analyze, ideate and develop circular innovation ecosystems.
\end{abstract}

Keywords: circular economy; innovation ecosystems; business models; innovation; design

\section{Introduction}

The circular economy may help firms to decarbonize and dematerialize their business activities [1,2]. Firms can pursue five integrated strategies towards a circular economy: they can narrow (use less material and energy), slow (use products and components longer), close (use material again), regenerate (use non-toxic material and renewable energy) and inform (use information technology to pursue circularity) the resource and energy flows that are associated with their business activities [2-5]. To combine these five strategies, firms need to transform the higher-order production and consumption systems that they form part of [6-13]. This requires a broad innovation perspective; one that innovates products/services, business models, and ecosystems [3,14-17]. Product/service innovation develops, produces and commercializes new products/services [18]. Business model innovation changes what a firm offers and to whom, how a firm creates and delivers the offering, and how it captures value from 
it [19-21]. Ecosystem innovation changes how a group of loosely coupled organizations interact with each other to achieve a collective outcome [16,22].

Existing tools and approaches that may help firms to improve their environmental sustainability have focused on product and business model innovation. Product-focused and firm-internal tools include eco-design tools like life-cycle assessment, diagrams, checklists and guidelines [23]. Product design tools propose strategies and principles to design for $X(X=$ maintenance, reparability, durability, behavior change, etc.) $[3,24,25]$. Business model innovation tools and approaches for sustainability or circularity $[26,27]$ include, for example, adapted versions of the business model canvas [28-30], maps of the value landscape of a firm [31], or maps of customer intervention points, where firms have more or less control over a product's lifecycle [32].

Many existing business model approaches have, albeit implicitly, taken system perspectives. For example, some approaches suggest the need to integrate multiple, complementary business models or value logics [33], collaborate with important stakeholders to achieve system-level sustainability [34], recognize trends, drivers and involve stakeholders at the ecosystem level [35], include the supply chain as a whole in innovation efforts [36], rethink complexity management for the circular economy [37], or experiment within an 'ecology of business models' [38]. However, none of these approaches differentiates between a business model and an ecosystem perspective [26,27], although this difference is well documented in the innovation and strategic management literatures [39,40]. In addition, existing tools for circular oriented innovation have rarely been tested in practice to understand their usefulness and ease of use $[26,27]$. This is problematic because tools from academic research may therefore not be used in practice, which reinforces the theory-practice gap of organizational research [41].

The objective of the present study is to address these two gaps in the literature on circular oriented innovation: (1) the need to integrate ecosystem perspectives into circular oriented innovation, and (2) the need to develop tools that are thoroughly evaluated against criteria like perceived usefulness and ease of use. This objective is guided by the following main research question: how can firms be facilitated to take an ecosystem perspective on circular oriented innovation?

To address this question, we develop the Circularity Deck: a card deck-based tool and approach to analyze, ideate and develop the circularity potential of innovation ecosystems. The tool is based on a literature and practice review of circular oriented innovation principles. Principles are solution-oriented guidelines [42] that can achieve a desired result [43]. Each principle is illustrated with an example. The principles and examples are organized according to the chosen circular strategy (i.e., narrow, slow, close, regenerate and inform material and energy flows), and the required scope of the innovation perspective to operationalize the principle (i.e., product, business model, or ecosystem innovation). This review and categorization process served to develop the Circularity Deck, which was subsequently tested for ease of use and perceived usefulness in 12 workshops with 136 participants from 62 different organizations, both incumbent and startups. The tool development process revealed that (1) clear and concise examples help the participants understand the tool content and concepts and make it more useful and easier to use, (2) participants may benefit from an exercise without the tool, to be free from the possible constraints that it might impose, and to show the participants its power once they get to use it, and (3) the tool is most useful when actively facilitated by an expert who is familiar with the background concepts. Our tool and categorization process may be enriched through future reviews of new principles and examples. While we intend to propose a generic Circularity Deck, future research may develop customized Circularity Decks for the mobility, food or construction industries as these industries have the highest global life-cycle environmental impact [44].

\section{Conceptual Background}

\subsection{An Ecosystem Perspective on the Circular Economy}

A circular economy maximizes the value of material resources and minimizes overall resource use, waste, pollution and emissions [1,2]. It is a systemic concept: authors have argued that a circular 
economy requires higher degrees of collaboration among actors [13,45], whole-systems design [8], a transformation of production and consumption systems [6,7], reverse/cascading skills, cross cycle and cross sector collaboration [12], a shift from supply chains to value networks [9], life-cycle thinking [11], and sustainable supply chain network designs [10]. The Ellen MacArthur Foundation, a popular advocate of the circular economy, has suggested that a circular food system, for example, "will require a global systems-level change effort that is cross-value chain [and that] spans public and private sectors" [46]. This suggestion illustrates that circularity-a situation in which economic and social structures are organized so that they maximize the value of material resources and minimize overall resource use, waste, pollution and emissions-is a property of a system; for example, the mobility system of a city, rather than a property of an individual product or service; for instance, a car or car sharing service [47,48]. As a systemic property, circularity is subject to emergence [49]: it emerges out of changes in how different actors, products, components and material interact with each other.

The existing literature on the circular economy has suggested that business model innovation may lead to higher circularity [50,51], because sustainable and circular business models take a broad perspective on a firm's value creation. They look at the value a firm creates; for itself, as well as for a its stakeholders, including the environment [28,31]. However, a business model perspective usually focuses on how one firm does business [52]. An ecosystem perspective goes beyond this level, because it pays equal attention to the business models of other relevant actors. It looks at how a multitude of business models could be combined to achieve a collective outcome [16,40]. We therefore argue that a business model perspective is too narrow to achieve higher levels of circularity [38]. In addition to product/service and business model innovation, it is necessary to widen the innovation perspective to include the 'ecosystem' (Figure 1) [16,39].

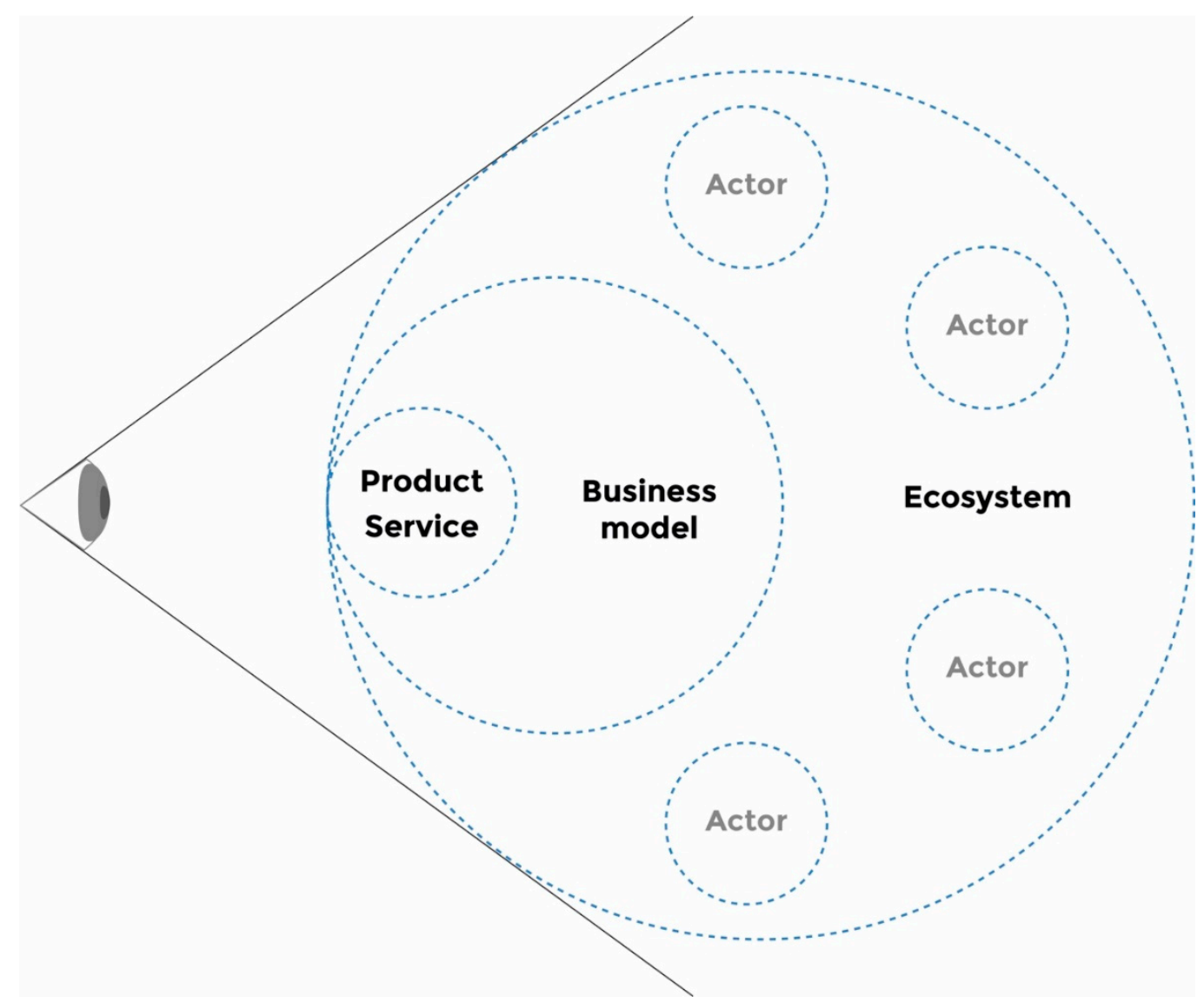

Figure 1. An ecosystem perspective: product/service, business model, and ecosystem. Source: Adapted from $[47,48,53]$. 
Ecosystems are comprised of any set of actors-producers, suppliers, service providers, end users, regulators, and civil society organizations-that contribute to a collective outcome [16,22]. Ecosystems have the following characteristics. They (1) consist of multiple locally, regionally or globally distributed entities that do not belong to a single organization, (2) involve dynamic, collaborative and competitive relationships, (3) imply flows of data, services, and money, (4) often involve complementary products, services and capabilities, and (5) evolve as actors constantly redefine their capabilities and relations to others [22,40]. Ecosystems are different from supply or value chains. The latter often involve bilateral supply relationships with clear upstream and downstream positions. Ecosystems on the other hand often involve a re-positioning of actors [39]. Ecosystem innovation aims at changing how actors relate to each other, and how they interact to achieve a desired outcome. This outcome can be achieved by developing co-specialized and complementary products and services [54]. Products and services are complementary if they are more valuable when combined than when they are used alone [22]. The value of a smartphone, for example, is higher when combined with apps. The same principle, we argue, applies to circular products and services: they often maximize their circularity in conjunction with other assets. For example, a product that contains recyclable materials, that has mono-material components, and that is easy to disassemble, only maximizes its 'recycling value' when embedded in a functioning collection system, and when treated in proper recycling facilities. A circular ecosystem perspective thus goes beyond the question "what is our value proposition?" Instead, it asks: "how does our offering complement other products and services that together can provide a superior and circular ecosystem value proposition?"

\subsection{Circular Strategies}

Firms can innovate towards a circular economy through five interrelated strategies. They can narrow, slow, close, regenerate and inform product, component, material and energy flows (Figure 2) [3,55-57]. The 'narrow', 'slow' and 'close' strategies have been proposed in previous research [3]. We add the strategy 'regenerate' to account for two additional aspects that are important for 'cleaner production' [58] and that have been stressed in early conceptions of the circular economy [5]: the minimized use of toxic substances; i.e., substances that are persistent and liable to bio-accumulate [59], and the need for an increase of renewable materials and energy in a circular economy [4,55]. In addition, we include 'inform' as a support strategy for firms because several publications have emphasized the importance of information technology in enabling a circular economy [57,60-63]. The blue line in Figure 2 indicates the key strategies that can influence material and energy flows. The grey line below the blue circle indicates the support strategy 'inform'. Each strategy can be decomposed into innovation principles (solution-oriented guidelines) [42]. These principles may require product, business model, or ecosystem perspectives. In the following, we describe each strategy and give some examples of corresponding product, business model and ecosystem innovation principles.

Narrowing refers to using fewer products, components, materials and energy during design and production [64], and during delivery, use and recovery [65]. A product principle for narrowing is 'design with low-impact inputs' [64]. Impossible Foods, for instance, has designed a plant-based burger with a meat texture. Compared to the beef alternative, it requires ca. $7 \mathrm{~m}^{2}$ less land, $300 \mathrm{~L}$ less water and $5 \mathrm{~kg}$ less $\mathrm{CO}_{2}[46,66]$. A business model principle for narrowing is, for instance, 'incentivize users to consume less'. An example is HOMIE, a company that offers washing machines through a pay-per-wash model, monitors user behavior and provides advice and price incentives to wash with lower temperatures and the right amount of detergent. As a result, the firm's users wash $30 \%$ less often and at lower average temperatures [67]. An ecosystem principle for narrowing is 'maximize the use capacity of products'. This is sometimes referred to as 'sharing', where multiple user groups have access to the same product. This sharing can decrease the overall number of products in an ecosystem. The online platform Peerby, for example, enables people to share everyday goods like drills or bicycles, which can increase their 
usage and reduce the overall number of personally owned goods in homes over time. Maximized use capacity may require the coordination of multiple actors in a given ecosystem [68-70].

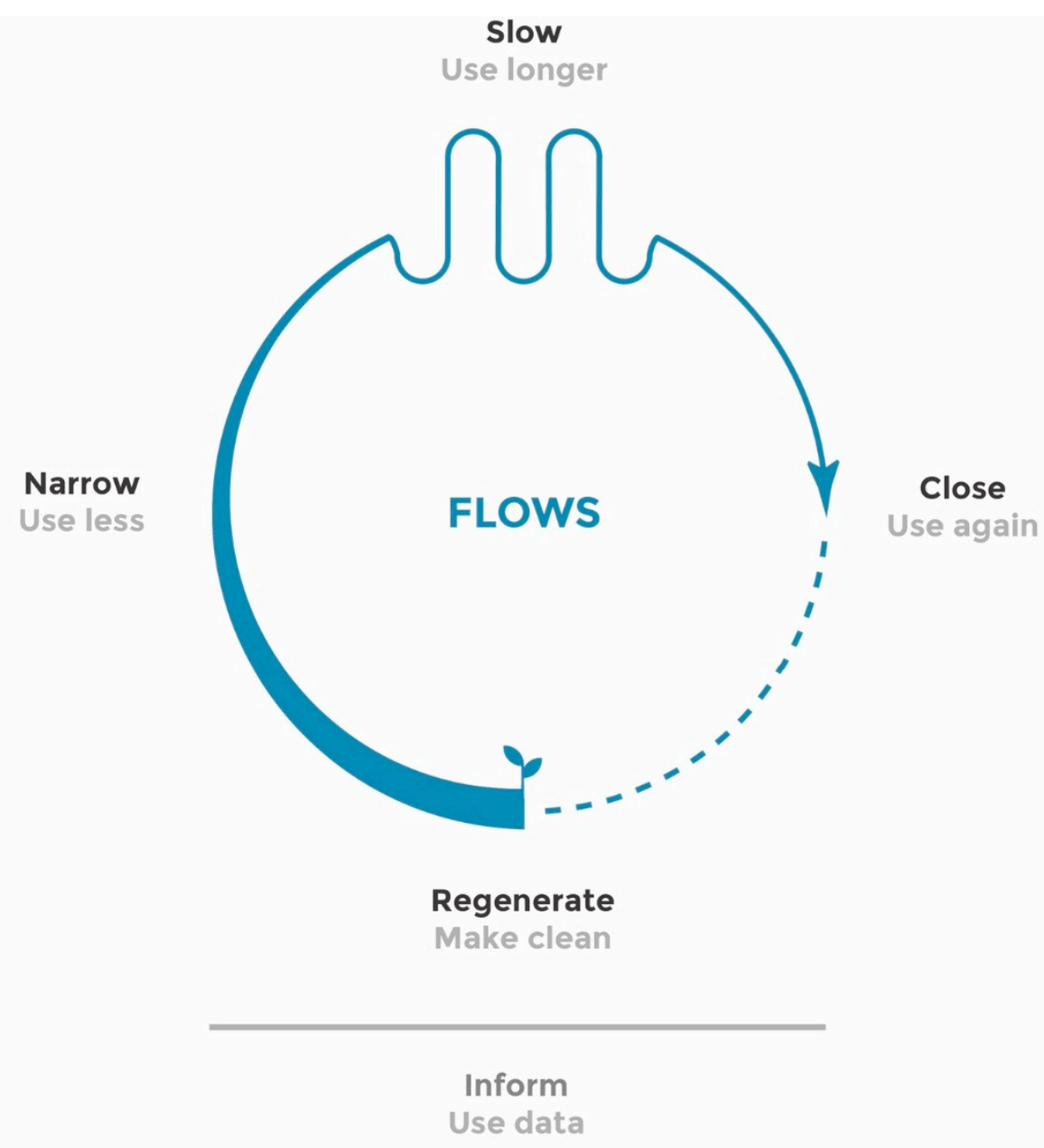

Figure 2. Circular strategies: narrow, slow, close, regenerate and inform material and energy flows.

Slowing refers to using products, components and materials longer [3,6,9,14,71,72]. A product principle for slowing is 'design for physical durability' [3]. A product is physically more durable if its performance over time degrades more slowly than comparable products on the market [73]. An example is a cast-iron pan, which can last longer than other pan types. A business model principle for slowing is 'offer the product as a service' [3,9,69,74-78]. Product-as-a-service models can be product-, use-, or results-oriented [75]. The company Kaer, for example, offers a result: cool and fresh air as a service, rather than air conditioners as products [79]. By focusing on results, companies like Kaer can minimize the resource intensity of their offering over time [14,79]. An ecosystem principle for slowing is 'turn disposables into a reusable service' [80,81]. TerraCycle, for example, has designed 'Loop' [82]. This service delivers popular consumer goods like shampoo or ice cream in reusable packaging. When new products are delivered, the packaging gets picked up, cleaned and will be used again. Loop is an ecosystem that involves several complementary products and services: end users who order Loop, TerraCycle who coordinates the platform and partnerships, several retail brands like Nestle or Unilever who provide their products in the suggested reusable packaging, as well as external service providers who transport and clean the packaging.

Closing refers to a business activity that brings post-consumer waste back into the economic cycle [3]. A product principle for closing is 'design with materials suitable for primary recycling'. Aquafil, for instance, has designed the 'Econyl system', which enables Polyamide 6 or Nylon 6 waste to be 
manufactured into new Nylon 6, with no loss of quality [83]. An example of a business model principle for closing is 'enable and incentivize product and component returns' [25]. An example is Teemill: this clothing company stimulates users to send back old and worn out products. Users can scan a QR code in the wash-care label to generate a free post label, which can be used to send the garment back to Teemill. Sending back products earns users credit for their next purchase [84]. An ecosystem principle for closing is 'organize local waste-to-product ecosystems' $[69,85]$. The company SOOP, for instance, has orchestrated an ecosystem of several actors that collect waste (coffee grounds and orange peels) from offices, process the waste into raw materials, produce new products from the raw materials (e.g., soap), and then deliver them back to the same offices [86].

Regenerating refers to a business activity that manages and sustains natural ecosystem services, uses renewable and nontoxic materials, and is powered by renewable energy [4,5]. This strategy mostly relates to the 'biological cycle' of the circular economy, but also contains elements that are relevant for the 'technical cycle', especially with regards to the use of renewable energy. A product principle for regenerating is 'design with non-toxic materials' [58,72,87-89]. Vestaron, for example, has found a way to substitute synthetic pesticides with biological ones that are safe for humans, birds, fish and pollinators $[46,90]$. A business model principle for regenerating is 'produce with renewable energy'. An example is the company Apple, which has an installed capacity for solar energy of over 400 MW [91]. An ecosystem principle for regenerating is 'recover nutrients from urban areas'. This principle is about identifying ways to recover valuable nutrients from urban areas that are usually lost. This may require different actors in an ecosystem like end users who produce nutrient output (in the form of sludge or organic waste), as well as firms who collect, transport, process and re-distribute the nutrients. Lystec Inc., for example, helps the city of Guelph to turn biosolids from wastewater treatment into organic nutrients that are then sold to farms in the area [46,92].

Finally, informing refers to using information technology as a support strategy for the circular economy $[57,60-63,93,94]$. We include this support strategy because several practice and research projects have highlighted the importance of information technology for a circular economy; for example, the role of artificial intelligence [63], the internet of things [93,94], big data [95], or online platforms [57]. While using information technology may support higher environmental sustainability, it can also lead to adverse effects [94,96]; for example, regarding the higher energy use requirements of digital infrastructure [94]. It is therefore important to highlight that information technology needs to be viewed as a means to an end (in this case circularity), and not as an end in itself. The ability of information technology to enable circularity therefore requires thorough assessments to understand its potential to reduce overall environmental impact. Most principles that can inform material and energy flows may support more than one circular strategy. A product principle to inform flows is, for example, 'design connected products' [60,93,97]. Connected products can slow flows by informing maintenance and repair needs. Delta Development, for instance, as part of their product-as-a-service' model, has sensors in some of their elevators to inform maintenance needs [93]. Connected products can also help to close flows by knowing the location of products at the end of their lives [93]. A business model principle for informing is 'track the resource intensity of the product-in-use'. Philips, for example, uses sensors in some of their lighting devices to track data on how their lights are used within their 'lighting-as-a-service' model to save electricity [94]. An ecosystem principle to inform flows is to 'operate service ecosystems via online platforms' [57]. An example is the online platform Whim, which operates mobility-as-a-service ecosystems in cities that include different private and public modes of transportation [98].

\subsection{Research Gaps and Goal of This Study}

The present study addresses two gaps in the extant literature on circular oriented innovation: (1) a lack of circular oriented innovation approaches that integrate an ecosystem perspective; and (2) the development of circular ecosystem innovation tool that is evaluated against its ease of use and perceived usefulness to ensure its practical relevance. To address both gaps, we propose 
the Circularity Deck: an approach and tool to analyze, ideate and develop the circularity potential of innovation ecosystems. Our objective is to make two main contributions to research and managerial practice. First, for research, the underlying literature and practice review for the Circularity Deck produces a novel way to analyze circular economy innovation strategies, principles and real-world examples. It thereby enables a practical and principle-based ecosystem perspective on the circular economy. Second, for practice, it turns this analysis into an easy-to-use and useful tool for firms to analyze, ideate and develop the circularity potential of their ecosystems. These two main contributions are guided by the following research question: How can firms be facilitated to take an ecosystem perspective on circular oriented innovation?

\section{Method}

Our research method is organized in two main steps. The first step contains a literature and practice review to derive a set of circular economy innovation principles and examples (Section 3.1). The second step uses a design research approach to make the principles useful for practice in the form of a card deck based tool [46]. The tool is iterated and improved through 12 workshops with 136 participants from 62 different firms (Section 3.2).

\subsection{Literature and Practice Review to Derive Principles}

The purpose of the literature and practice review is to derive a set of principles and examples of circular economy oriented innovation. Principles are solution-oriented guidelines [42] that can be organized according to the context, intervention, mechanism, outcome (CIMO) logic: the context (the context in which people act), the intervention (the action that happens), the mechanism (the change that the action triggers) and the intended outcome (the resulting situation). The CIMO logic is useful in a design science context, in which research intends to produce prescriptive knowledge that is useful for practitioners [43]. In this study, the context is business innovation towards a circular economy. The intervention is an action that one can take using a product, a business model, and/or an ecosystem perspective; for instance, 'design with low-impact inputs' (a product perspective). The strategic mechanism is the narrowing, slowing, closing, regenerating or informing and the intended outcome is to maximize the value of material resources, and to minimize overall resource use, emissions, waste and pollution. Each principle is supported with a real-world example that illustrates its practical use.

The literature review was conducted with the help of Scopus, one of the largest academic databases. We searched for articles using a number of search strings to identify principles that can narrow, slow, close, regenerate and inform resource and energy flows, for the circular economy in general, and for the circular strategies in particular. For example, for 'narrowing', we looked for reduce AND sustainability AND strategies OR principles. Due to the focus on firms, we filtered for 'business, accounting and management journals'. The titles, keywords and abstracts of the top 30 cited articles of each of the applied search strings were scanned as to whether they develop or propose prescriptive knowledge in the form of circular oriented design and/or innovation principles. We excluded generic literature reviews or analytical models. This led to 23 selected articles, which were then read to retrieve the principles. Consistent with the framework of this study, we coded these principles according to the type of circular strategy that they propose (i.e., narrow, slow, close, regenerate, inform), and whether they apply to the product, the business model, or the ecosystem. In addition, we retrieved real-life examples if we found them in the articles. Appendix A lists all applied search strings and the selected articles from each search.

The practice review complemented the literature review. Often, practice information is ahead of the academic literature and may contain valuable insights for research [99,100]. We focused the practice review on identifying examples that match the principles. If an example did not match a principle, then we added the principle based on the example. The practice examples were retrieved from the internet (i.e., circular economy related websites, blogs, articles, websites) and the grey literature (e.g., practice reports on circular economy) to complement the results derived from the literature. We searched 
Google and used the strings ["circular economy" AND principles OR strategy*]. From the first three pages in Google, we selected a number of publications and case studies from reputable organizations and projects in the circular economy field. The publications and case studies we selected came from The Ellen Macarthur Foundation [46,93,101,102], IDEO Circular Design Guide [103] and the ResCom project [104]. Figure 3 summarizes the process of the literature and practice review.

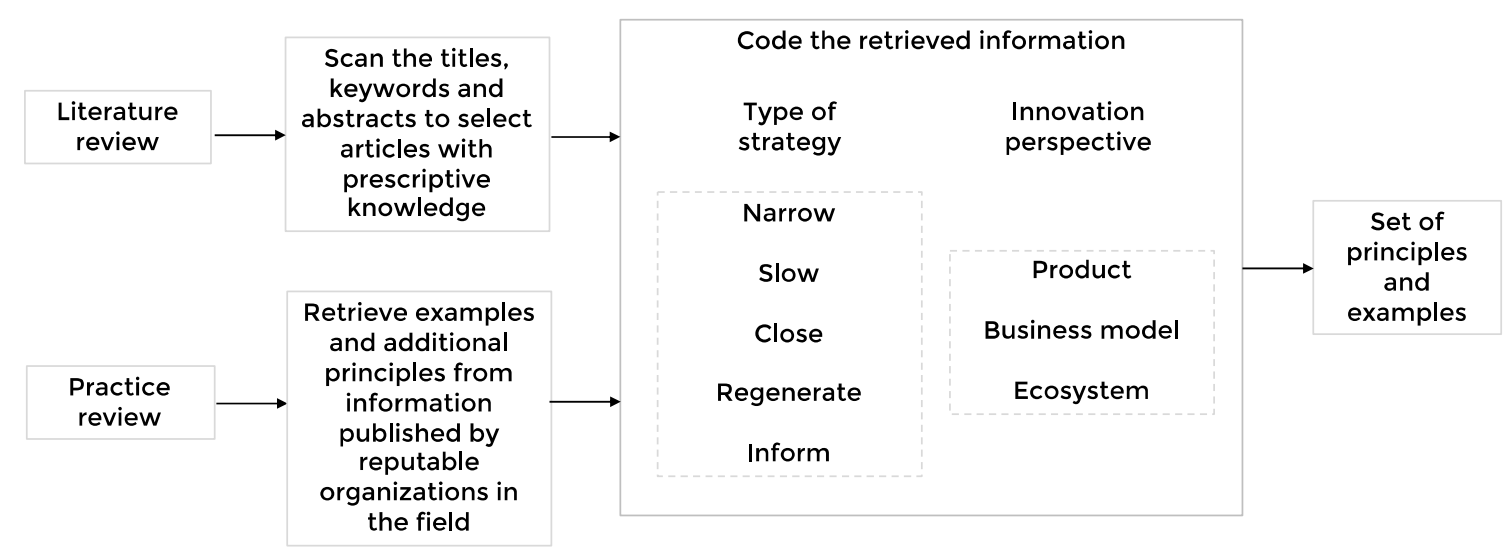

Figure 3. The process of the literature and practice review.

\subsection{Tool Development and Evaluation}

A tool is "a generic name for frameworks, concepts, models, or methods" [105]. Tools codify knowledge and make it useful for researchers and practitioners to improve their decisions and actions (ibid.). The principles and examples from the literature and practice review were used to develop the Circularity Deck as a tool that enables firms to take an ecosystem perspective on the circular economy. The goal of the tool is to help firms analyze, ideate and develop the potential circularity of their innovation ecosystems. The intended user groups include entrepreneurs, innovation managers, business managers, and designers who want to innovate towards a circular economy. The tool should contain guidance on how it can be used, be adaptable to different contexts [27], easy to use, haptic and playful. To fulfill this, we decided to base the tool on the use of cards. Design research has recognized cards as an engaging approach to learning and ideating [106,107]. Principles of design research include, for example, engaging stakeholders and users, early testing and prototyping, and taking an iterative approach to developing and testing $[108,109]$. Design research has become popular to address sustainability issues on a more strategic level [110,111], next to its obvious use in product design [48], perhaps because of its potential to address wicked issues such as climate change and resource issues [112].

To evaluate and improve the Circularity Deck, we conducted 12 workshops with 136 participants from 62 different organizations. These workshops were conducted with entrepreneurs ( 7 sessions), innovation and business managers in incumbent firms ( 3 sessions), and designers from design agencies ( 2 sessions) in the following contexts:

- An incumbent firm from the health technology sector (nine participants) who worked on refurbishing and servitizing one of their products;

- Twelve 'circular startups' that were part of the 'Investment Ready Programme' 2018 of the Impact Hub in Amsterdam, Netherlands, an organization that promotes impact entrepreneurship (15 participants). One startup worked on, for example, providing solid home cleaning products under a subscription;

- A mobility design agency based in Amsterdam working on a new shared mobility solution for a client (six participants);

- A group of entrepreneurs and firm managers from the province of Noord Holland. The workshop was conducted at Impact Hub in Amsterdam (21 participants). One example from the group included a startup that makes euro pellets from otherwise wasted coconut fibers; 
- A large engineering service company in the Dutch construction sector (five participants) that wanted to explore how they can offer more circular oriented services in their portfolio;

- A group of entrepreneurs (21 participants) in Lund, Sweden, as part of an international coaching program to develop their circular business models. One group worked on, for instance, how to turn the textile sector circular;

- A group of entrepreneurs, innovation managers and researchers. The workshop was conducted at Impact Hub in Hamburg, Germany (15 participants). One group worked on, for instance, how to make plastic packaging in the fast moving consumer goods sector circular;

- A group of entrepreneurs and innovation managers who joined a workshop as part of a conference in Riga, Latvia (18 participants). One group worked on, for example, establishing a local marketplace for wasted building materials;

- A design agency based in Helsinki, Finland (6 participants) that wanted to explore how they can integrate circularity into their service design offerings;

- A group of entrepreneurs, innovation managers, designers and researchers from the Helsinki region, Finland (5 participants). One challenge that the group addressed related to a systemic textile project to make Finland's textile industry circular;

- A group of entrepreneurs, innovation managers and researchers from the Helsinki region, Finland (10 participants). One challenge that a group addressed was how to provide circular operating services for buildings;

- A group of entrepreneurs, innovation managers and researchers from the Lappeenranta region, Finland (10 participants). One group included a chairman and an environmental manager from a big welding company that wanted to explore the circularity of their operations and business model.

We used a simplified version of a well-known technology assessment model to evaluate the ease of use and perceived usefulness of our tool [113]. At the end of each workshop, we distributed a form among participants, which stated: "The purpose of the Circularity Deck is to map and analyze circular ecosystems." It then asked participants to evaluate whether "The Circularity Deck was useful to address the purpose stated above" and whether "The Circularity Deck was easy to use". For both statements, we provided a Likert scale from 1-5 ( $1=$ completely disagree, $5=$ completely agree), and included space for qualitative feedback. The form can be found in Appendix B. Appendix C contains the complete qualitative information obtained from the forms. We used this information after each workshop to make changes to the tool. The focus was on lower ratings and associated comments. We went through the qualitative feedback and retrieved ideas for improvement. Through discussions among the co-authors of this study, we evaluated which of the proposed changes to incorporate. The results Section 4.3 covers the proposed changes, what we changed, and what we did not change, based on the user feedback.

\section{Results}

\subsection{The Circularity Deck}

The Circularity Deck enables participants to analyze, ideate and develop the circularity potential of their innovation ecosystems. It contains product, business model and ecosystem innovation principles that can narrow, slow, close, regenerate and inform material and energy flows in a given context, and to analyze which actors are needed to be able to do so. Figure 4 shows some example cards (front and back). The colors indicate the circular strategy: orange represents 'narrow', red 'slow', blue 'close', green 'regenerate' and grey 'inform'. The front of each card contains a principle and indicates whether it is a product, business model or ecosystem principle (bottom left of the front card). The back side of each card contains a short description of each principle and an example. The full content of the Circularity Deck is listed in Table 1. 


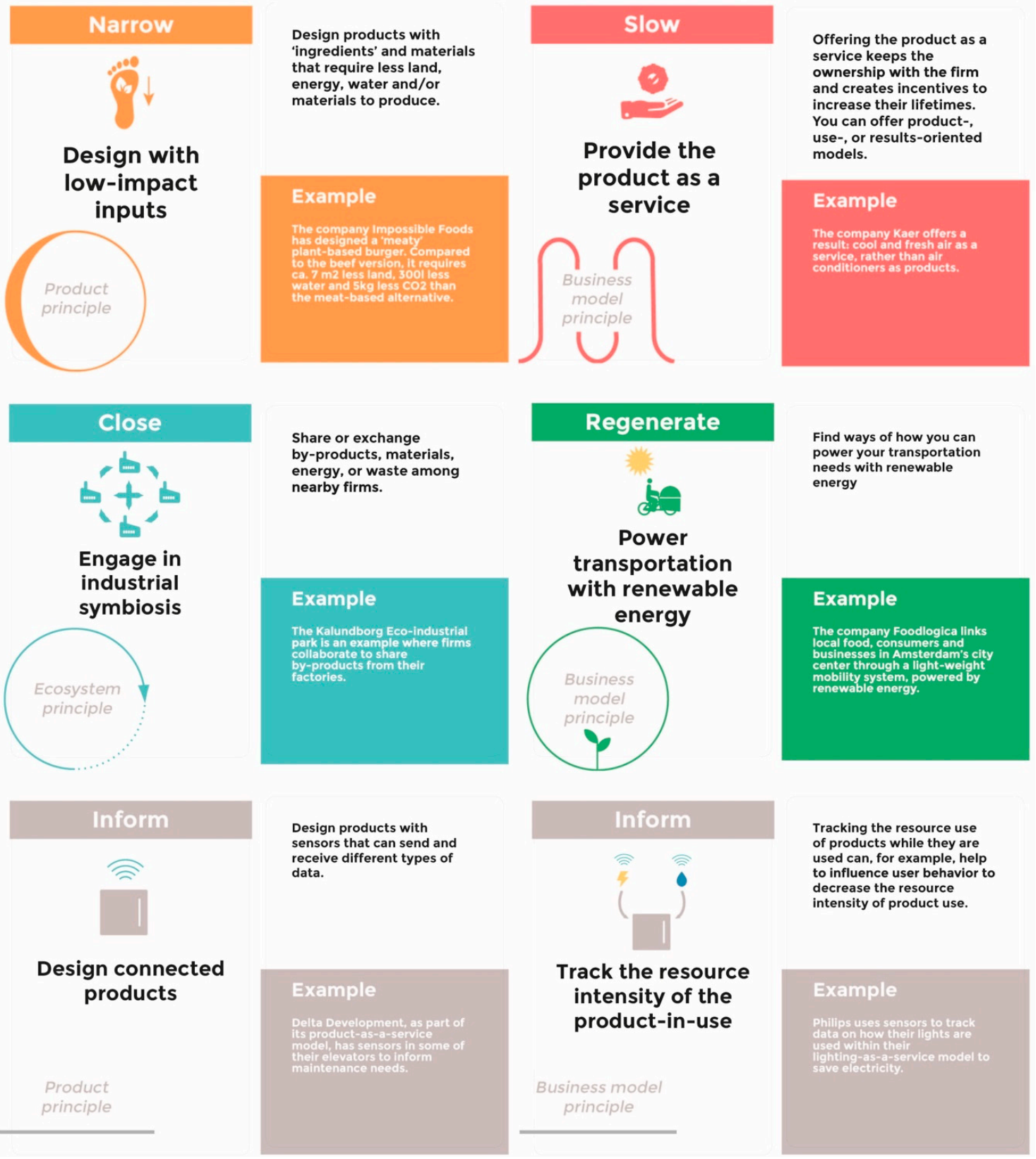

Figure 4. Example cards from the Circularity Deck. 
Table 1. The Circularity Deck: a set of circularity principles for product, business model and ecosystem innovation.

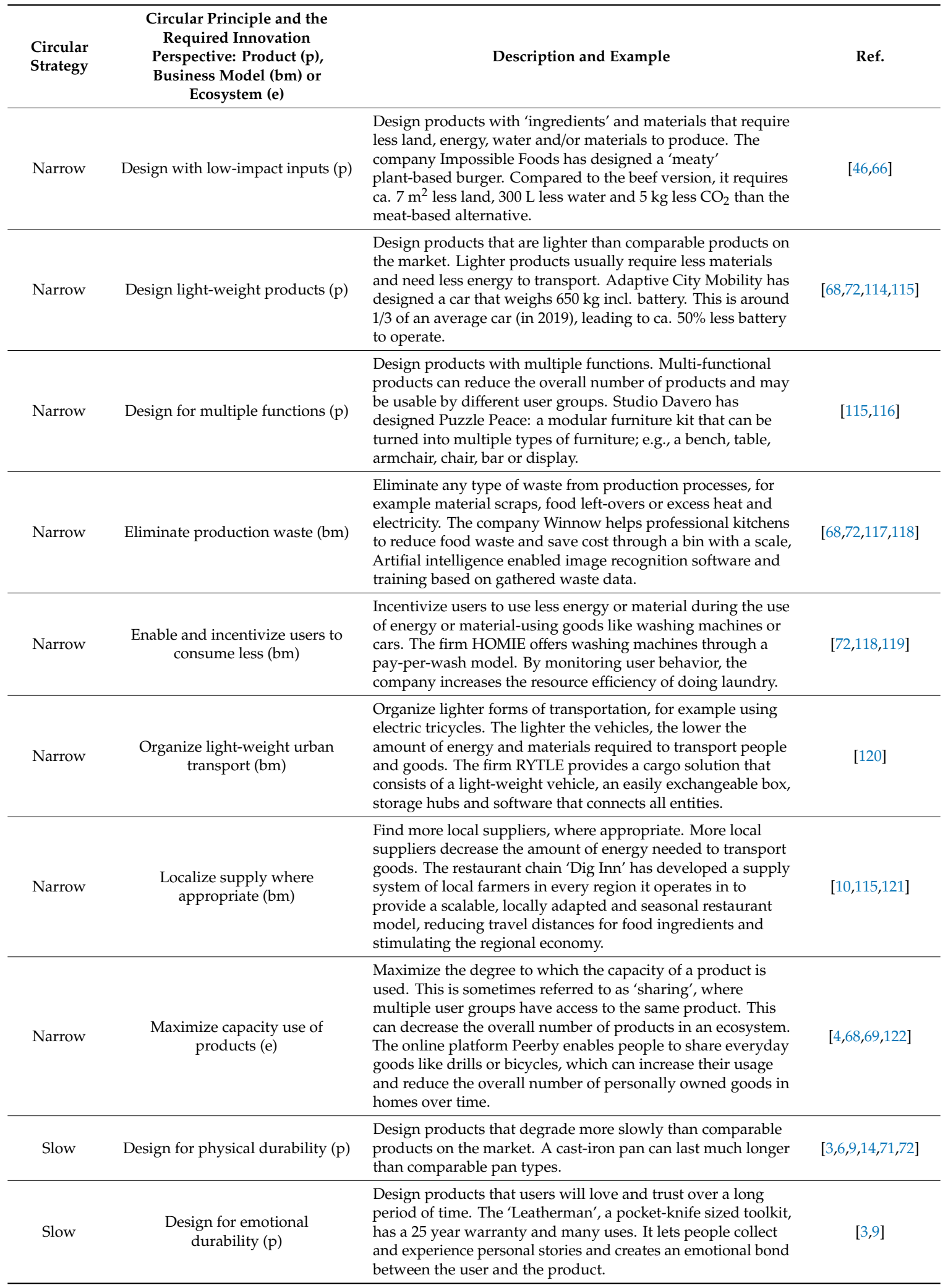


Table 1. Cont.

\begin{tabular}{|c|c|c|c|}
\hline $\begin{array}{l}\text { Circular } \\
\text { Strategy }\end{array}$ & $\begin{array}{l}\text { Circular Principle and the } \\
\text { Required Innovation } \\
\text { Perspective: Product (p), } \\
\text { Business Model (bm) or } \\
\text { Ecosystem (e) }\end{array}$ & Description and Example & Ref. \\
\hline Slow & $\begin{array}{l}\text { Design for ease of maintenance } \\
\text { and repair }(\mathrm{p})\end{array}$ & $\begin{array}{l}\text { Design products that can be easily maintained or repaired. } \\
\text { Maintaining means inspecting the product to retain its } \\
\text { functional capabilities. Repairing is about restoring a product } \\
\text { to a sound/good condition after decay or damage. Fairphone } \\
\text { has designed a modular phone that can be easily disassembled } \\
\text { to repair and exchange components. }\end{array}$ & {$[3,6,14,58,68,72]$} \\
\hline Slow & $\begin{array}{l}\text { Design for easy dis - and } \\
\text { reassembly }(\mathrm{p})\end{array}$ & $\begin{array}{l}\text { Design products that can be easily separated and reassembled. } \\
\text { Gerrard Street has designed a pair of headphones that can be } \\
\text { easily separated and reassembled. }\end{array}$ & {$[3,123]$} \\
\hline Slow & Design for upgradability (p) & $\begin{array}{l}\text { A product is upgradable if its functionality or performance } \\
\text { can be improved during or after use. An example is a bicycle } \\
\text { with exchangeable and upgradable components. }\end{array}$ & {$[3,6,72,124,125]$} \\
\hline Slow & $\begin{array}{l}\text { Enable users to maintain and } \\
\text { repair their products (bm) }\end{array}$ & $\begin{array}{l}\text { Create services that enable users to care for their product. } \\
\text { Fairphone supports users to care for their phones through } \\
\text { discussion forums on how to maintain and repair, and an } \\
\text { inventory of spare parts. }\end{array}$ & {$[25,126]$} \\
\hline Slow & $\begin{array}{l}\text { Remanufacture existing products } \\
\text { and components (bm) }\end{array}$ & $\begin{array}{l}\text { Recover value from collected end-of-use products by reusing } \\
\text { their components for the manufacturing of products with the } \\
\text { same functionality. The Chinese company Guangzhou Huadu } \\
\text { collects used vehicle parts and remanufactures them into } \\
\text { as-new certified spare parts. }\end{array}$ & {$[9,118,125,127]$} \\
\hline Slow & $\begin{array}{l}\text { Repurpose existing products and } \\
\text { components (bm) }\end{array}$ & $\begin{array}{l}\text { Take existing products and components and take them out of } \\
\text { their context to create new value with them. Ubitricity turns } \\
\text { lamp lanterns in cities into charging stations for electric } \\
\text { vehicles. }\end{array}$ & {$[128,129]$} \\
\hline Slow & Encourage sufficiency (bm) & $\begin{array}{l}\text { Encourage your customers to moderate the consumption of } \\
\text { your products. In 2011, the clothing company Patagonia } \\
\text { advocated: "Don't buy this jacket." With Worn Wear, it opened } \\
\text { an online store for used Patagonia clothing, encouraging users } \\
\text { to maintain their gear and trade it back once they don't use it } \\
\text { anymore. }\end{array}$ & {$[21,68]$} \\
\hline Slow & $\begin{array}{l}\text { Provide the product as a } \\
\text { service }(\mathrm{bm})\end{array}$ & $\begin{array}{l}\text { Offering the product as a service keeps the ownership with the } \\
\text { firm and creates incentives to increase their lifetimes. You can } \\
\text { offer product-, use-, or results-oriented models. The company } \\
\text { Kaer offers a result: cool and fresh air as a service, rather than } \\
\text { air conditioners as products. }\end{array}$ & {$[3,9,69,74-78,122]$} \\
\hline Slow & $\begin{array}{l}\text { Organize maintenance and repair } \\
\text { services }(\mathrm{bm})\end{array}$ & $\begin{array}{l}\text { Make sure that your products can last longer through } \\
\text { maintenance and repair services. They can be offered by the } \\
\text { manufacturer of a product or by third-party providers. The } \\
\text { company Nudie Jeans, at its point of sale, has started to offer a } \\
\text { free repair service for their Jeans. This has changed the shop } \\
\text { appearance into a craftsmanship atmosphere. }\end{array}$ & {$[122,124,131]$} \\
\hline Slow & $\begin{array}{l}\text { Upgrade and adapt existing } \\
\text { products }(\mathrm{bm})\end{array}$ & $\begin{array}{l}\text { A product is upgradable if its functionality or performance } \\
\text { can be improved during or after use. Try and integrate } \\
\text { upgrading services into your offering. Gispen offers } \\
\text { REMADE, a service to repurpose old furniture to fit new } \\
\text { trends and workspace requirements. }\end{array}$ & {$[122,124,128,129,132]$} \\
\hline
\end{tabular}


Table 1. Cont

\begin{tabular}{|c|c|c|c|}
\hline $\begin{array}{l}\text { Circular } \\
\text { Strategy }\end{array}$ & $\begin{array}{l}\text { Circular Principle and the } \\
\text { Required Innovation } \\
\text { Perspective: Product (p), } \\
\text { Business Model (bm) or } \\
\text { Ecosystem (e) }\end{array}$ & Description and Example & Ref. \\
\hline Close & Design with recycled inputs $(p)$ & $\begin{array}{l}\text { Design with materials that have been recycled from other } \\
\text { products and components. The 'Design for Recycled Content } \\
\text { Guide' supports firms in opting for more recycled content in } \\
\text { their products. }\end{array}$ & [133-136] \\
\hline Close & $\begin{array}{l}\text { Design components, where } \\
\text { appropriate, with one material (p) }\end{array}$ & $\begin{array}{l}\text { Composite materials are often hard to recycle because they } \\
\text { cannot be separated. Design components, therefore, where } \\
\text { appropriate, with only one material to increase recyclability. } \\
\text { Adidas has launched Futurecraft.Loop, a shoe made from one } \\
\text { recyclable material and no glue. It can be recycled into pellets } \\
\text { that can be turned into a new shoe. }\end{array}$ & {$[69,72,137]$} \\
\hline Close & $\begin{array}{l}\text { Design with materials suitable for } \\
\text { primary recycling }(\mathrm{p})\end{array}$ & $\begin{array}{l}\text { Try and design for primary recycling, that is: recycling that } \\
\text { can turn materials into materials with equivalent properties. } \\
\text { Aquafil has designed the Econyl system, which enables } \\
\text { Polyamide } 6 \text { or Nylon } 6 \text { waste to be manufactured into new } \\
\text { Nylon 6, with no loss of quality. }\end{array}$ & {$[68,83]$} \\
\hline Close & $\begin{array}{l}\text { Design for easy disassembly at the } \\
\text { end of the product lives ( } \mathrm{p})\end{array}$ & $\begin{array}{l}\text { Easy disassembly allows product components to be more } \\
\text { easily recycled. Magnomer uses magnetizable ink on } \\
\text { packaging labels to allow for easier separation during the } \\
\text { recycling process. }\end{array}$ & {$[3,138,139]$} \\
\hline Close & $\begin{array}{l}\text { Reuse and sell components and } \\
\text { materials from discarded } \\
\text { products }(\mathrm{bm})\end{array}$ & $\begin{array}{l}\text { Create new value from wasted products and components. } \\
\text { Roetz recovers bicycle components that were thrown away } \\
\text { and uses them to let customers assemble their own bikes. }\end{array}$ & [140] \\
\hline Close & $\begin{array}{l}\text { Enable and incentivize product } \\
\text { returns }(\mathrm{bm})\end{array}$ & $\begin{array}{l}\text { Make sure that you can get the products back that you put on } \\
\text { the market. The clothing company Teemill makes users send } \\
\text { back old and worn out products. Users can scan a QR code in } \\
\text { the wash-care label to generate a free post label, which can be } \\
\text { used to send the garment back to Teemill. Sending back } \\
\text { products earns users credit for their next purchase. }\end{array}$ & {$[25,84,122]$} \\
\hline Close & $\begin{array}{l}\text { Recycle products in proper } \\
\text { facilities }(\mathrm{bm})\end{array}$ & $\begin{array}{l}\text { Make sure that the products you put on the market get } \\
\text { recycled in proper facilities. The initiative 'Closing the Loop' } \\
\text { supports users and sellers of phones to be material-neutral } \\
\text { and waste free. It collects scrap phones on behalf of customers } \\
\text { and recycles them. }\end{array}$ & [141] \\
\hline Close & $\begin{array}{l}\text { Build local waste-to-product } \\
\text { loops (e) }\end{array}$ & $\begin{array}{l}\text { Create local resource loops by turning the waste of a given } \\
\text { facility into new products that can be sold back to the facility. } \\
\text { The firm SOOP has designed an ecosystem that collects waste } \\
\text { (coffee grounds and orange peels) from offices, processes it, } \\
\text { and re-delivers products to the offices that are made from to } \\
\text { the waste. }\end{array}$ & {$[69,85,86]$} \\
\hline Close & Engage in industrial symbiosis (e) & $\begin{array}{l}\text { Share or exchange by-products, materials, energy, or waste } \\
\text { among nearby firms. The Kalundborg Eco-industrial park is } \\
\text { an example where firms collaborate to share by-products from } \\
\text { their factories. }\end{array}$ & {$[3,7,69,142]$} \\
\hline Regenerate & $\begin{array}{l}\text { Design with renewable } \\
\text { materials }(p)\end{array}$ & $\begin{array}{l}\text { Design products with renewable and low-carbon materials. } \\
\text { Timber wood, for example, can replace non-renewable } \\
\text { building materials. Renewable materials should only be } \\
\text { chosen when its extraction rate is equal to or lower than its } \\
\text { recovery rate. Further, next to its properties, materials need to } \\
\text { be selected based on their expected end-of-life treatment to } \\
\text { avoid unintended consequences. }\end{array}$ & {$[3,5,69,143]$} \\
\hline Regenerate & Design self-charging products $(\mathrm{p})$ & $\begin{array}{l}\text { Design products that can charge themselves with renewable } \\
\text { energy. This is especially relevant for mobility assets. The } \\
\text { company Sono Motors has designed a car with solar cells } \\
\text { integrated into its body, allowing it to charge itself throughout } \\
\text { the day. }\end{array}$ & [144] \\
\hline Regenerate & Design with living materials (p) & $\begin{array}{l}\text { Living materials leverages the properties of natural materials. } \\
\text { Ecovative, for example, produces mycelium-based fibers and } \\
\text { materials with natural glue properties. Used for packaging, } \\
\text { apparel and in the medical industries. }\end{array}$ & [145] \\
\hline Regenerate & $\begin{array}{l}\text { Design with non-toxic } \\
\text { materials }(p)\end{array}$ & $\begin{array}{l}\text { Avoid using toxic materials and substances in any of your } \\
\text { products or operations. Toxic substances tend to accumulate } \\
\text { in the biosphere and cause negative health effects for humans } \\
\text { and other species. Vestaron substitutes synthetic pesticides } \\
\text { with biological ones that are safe for humans, birds, fish and } \\
\text { pollinators. }\end{array}$ & {$[58,72,87,89,90,146]$} \\
\hline
\end{tabular}


Table 1. Cont.

\begin{tabular}{|c|c|c|c|}
\hline $\begin{array}{l}\text { Circular } \\
\text { Strategy }\end{array}$ & $\begin{array}{l}\text { Circular Principle and the } \\
\text { Required Innovation } \\
\text { Perspective: Product (p), } \\
\text { Business Model (bm) or } \\
\text { Ecosystem (e) }\end{array}$ & Description and Example & Ref. \\
\hline Regenerate & $\begin{array}{l}\text { Produce and process with } \\
\text { renewable energy }(\mathrm{bm})\end{array}$ & $\begin{array}{l}\text { Build up your capacity as a company to produce and process } \\
\text { with renewable energy. In 2019, Apple has been the company } \\
\text { with the biggest installed capacity for solar energy, } 400 \text { MW. }\end{array}$ & [91] \\
\hline Regenerate & $\begin{array}{l}\text { Power the use of the product with } \\
\text { renewable energy (bm) }\end{array}$ & $\begin{array}{l}\text { Find ways of powering your product with renewable energy, } \\
\text { through creative partnerships or product and service design. } \\
\text { Waka Waka provides portable devices with photovoltaic } \\
\text { panels that can power every-day electronics. }\end{array}$ & [148] \\
\hline Regenerate & $\begin{array}{l}\text { Recover nutrients from urban } \\
\text { areas (e) }\end{array}$ & $\begin{array}{l}\text { Find ways of recovering valuable nutrients from urban areas } \\
\text { that are usually lost. Lystec Inc. helps the city of Guelph to } \\
\text { turn biosolids from wasterwater treatment into organic } \\
\text { nutrients for surrounding agriculture. }\end{array}$ & {$[46,92]$} \\
\hline Regenerate & $\begin{array}{l}\text { Regenerate polluted } \\
\text { ecosystems (e) }\end{array}$ & $\begin{array}{l}\text { Contribute to regenerating polluted ecosystems that affect } \\
\text { your business. The Ocean Cleanup Project develops } \\
\text { technology to clean oceans from plastic pollution. }\end{array}$ & [150] \\
\hline Regenerate & $\begin{array}{l}\text { Manage and sustain critical } \\
\text { ecosystem services (e) }\end{array}$ & $\begin{array}{l}\text { Engage in projects that manage and sustain the natural } \\
\text { ecosystems that surround and/or affect your business } \\
\text { operations. Nestle's Häagen-Dazs has partnered with the } \\
\text { nonprofit Xerces Society to plant the largest pollinator habitat } \\
\text { in the United States. Without pollination services from bees, } \\
\text { many critical ingredients for the ice-cream would not exist } \\
\text { anymore. }\end{array}$ & {$[151,152]$} \\
\hline Inform & Virtualize (p) & $\begin{array}{l}\text { Deliver utility virtually. Virtualizing reduces the need for } \\
\text { materials to deliver the same utility. reMarkable has designed } \\
\text { a digital device that "feels like paper". A tool for note-taking, } \\
\text { reading and reviewing documents. }\end{array}$ & {$[4,154]$} \\
\hline Inform & Design connected products $(\mathrm{p})$ & $\begin{array}{l}\text { Design products with sensors that can send and receive } \\
\text { different types of data. Delta Development, as part of its } \\
\text { 'product-as-a-service' model, has sensors in some of their } \\
\text { elevators to inform maintenance needs. }\end{array}$ & {$[62,155-159]$} \\
\hline Inform & $\begin{array}{l}\text { Use product-in-use data for } \\
\text { circular design (bm) }\end{array}$ & $\begin{array}{l}\text { Data on how a product is used can be valuable to make better } \\
\text { design decisions for future products and services. Rolls-Royce } \\
\text { aggregates product-in-use data to make their engines more } \\
\text { efficient, durable and long-lasting. }\end{array}$ & {$[57,60,62,158]$} \\
\hline Inform & $\begin{array}{l}\text { Track the resource intensity of the } \\
\text { product-in-use (bm) }\end{array}$ & $\begin{array}{l}\text { Tracking the resource use of products while they are used can, } \\
\text { for example, help to influence user behavior to decrease the } \\
\text { resource intensity of product use. Philips uses sensors to track } \\
\text { data on how their lights are used within their } \\
\text { lighting-as-a-service model to save electricity. }\end{array}$ & [95] \\
\hline Inform & $\begin{array}{l}\text { Track the condition, location, } \\
\text { and/or availability of the } \\
\text { product (bm) }\end{array}$ & $\begin{array}{l}\text { Tracking the condition of the products can help to predict } \\
\text { when it will be necessary to service (e.g., repair, maintain) } \\
\text { them. Tracking the location and availability can, for example, } \\
\text { enable the maximizing of their use capacity. Zipcar uses the } \\
\text { data to optimize their car sharing service. }\end{array}$ & {$[57,160]$} \\
\hline
\end{tabular}


Table 1. Cont.

\begin{tabular}{|c|c|c|c|}
\hline $\begin{array}{l}\text { Circular } \\
\text { Strategy }\end{array}$ & $\begin{array}{l}\text { Circular Principle and the } \\
\text { Required Innovation } \\
\text { Perspective: Product (p), } \\
\text { Business Model (bm) or } \\
\text { Ecosystem (e) }\end{array}$ & Description and Example & Ref. \\
\hline Inform & $\begin{array}{l}\text { Build material database } \\
\text { ecosystems (e) }\end{array}$ & $\begin{array}{l}\text { Create or leverage material databases. They describe the } \\
\text { characteristics of materials and components in products so } \\
\text { that products can be more easily reused and their materials } \\
\text { recovered. The project 'Buildings as Material Banks' has } \\
\text { brought together different stakeholders to develop a material } \\
\text { database ecosystem for buildings. }\end{array}$ & {$[161,162]$} \\
\hline Inform & $\begin{array}{l}\text { Co-create products, components, } \\
\text { materials and information via } \\
\text { online platforms (e) }\end{array}$ & $\begin{array}{l}\text { Online platforms can be used to 'crowdsource' design projects } \\
\text { for circular products, components and materials. The online } \\
\text { platform launchforth.io connects designers and engineers with } \\
\text { firms to co-create new products. }\end{array}$ & {$[57,163]$} \\
\hline Inform & $\begin{array}{l}\text { Use artificial intelligence to } \\
\text { optimize circular infrastructure (e) }\end{array}$ & $\begin{array}{l}\text { The circular economy requires the collecting, sorting, } \\
\text { separating, treating, and redistributing of products, } \\
\text { components and materials. Often, products, components and } \\
\text { materials are diverse and difficult to handle. Artificial } \\
\text { intelligence can help to optimize the infrastructure required } \\
\text { for a circular economy. ZenRobotics uses robots with cameras } \\
\text { and sensors to automatically sort all kinds of waste streams } \\
\text { with an accuracy level of } 98 \% \text {. }\end{array}$ & {$[63,158,164]$} \\
\hline Inform & $\begin{array}{l}\text { Operate service ecosystems via } \\
\text { online platforms (e) }\end{array}$ & $\begin{array}{l}\text { Online platforms can serve to operate service ecosystems that } \\
\text { require several actors who need to coordinate their } \\
\text { interactions and economic exchange. The online platform } \\
\text { Whim operates mobility-as-a-service ecosystems in cities } \\
\text { combining different private and public transportation options } \\
\text { for a seamless mobility experience. }\end{array}$ & {$[57,62,63,165]$} \\
\hline
\end{tabular}

\subsection{How to Use the Circularity Deck}

The use of the Circularity Deck is best illustrated with an example. Figure 5 shows the outcome of an exercise to analyze, ideate and develop the circularity potential of a hypothetical food ecosystem. The following paragraph describes the actions that could be derived from analyzing the identified principles with the circular economy framework.

Retailers and local restaurants may increase their share of plant-based versus animal-based product offerings. This example applies a product principle for narrowing: 'design with low-impact inputs'. They may start experimenting with systems for reusable packaging that is collected, cleaned and used again, which is an ecosystem principle for slowing: 'turn disposables into a service ecosystem for reuse'. Food-especially fresh produce sold in the supermarkets and through the restaurant dishes - can be sourced, if appropriate, from peri-urban farm areas to reduce travel distances, which is a business model principle for narrowing: 'localize supply where appropriate'. Transportation vehicles can be shared with fleet operators from other sectors (e.g., cars that can be used for last-mile food logistics, but also for taxi rides) to maximize their capacity utilization, which is an ecosystem principle for narrowing: 'maximize capacity use'. Transportation vehicles can be easy to maintain and repair, which is a product principle for slowing: 'design for ease of maintenance and repair'. Furthermore, the vehicles can be supported with product life-extension services like maintenance and repair, which applies a business model principle for slowing: 'organize maintenance and repair services'. The transportation vehicles can be powered with renewable energy, applying a business model principle for regenerating: 'power transportation with renewable energy'. The food left-overs from retail stores, restaurants and homes can be collected in local composting hubs that are then brought back to peri-urban areas to regenerate soil for further food production; an ecosystem principle for regenerating: 'recover nutrients from urban areas'. Finally, the food retailers may collaborate with local farmers to create space for bees surrounding their farms to ensure the supply of valuable inputs that require pollination; an ecosystem principle: 'manage and sustain ecosystem services'. The amount of food waste in restaurants can be tracked through Artificial Intelligence enabled image recognition technology to then train staff on how to reduce food waste in the kitchen; a business model principle for informing: 'track the resource intensity of the product-in-use'. Online platforms can serve to 
market food that is about to be thrown away in restaurants; an ecosystem principle for informing: 'market circular products, components and materials through online platforms'. Figure 6 presents a photograph of how the cards have been used in a workshop.

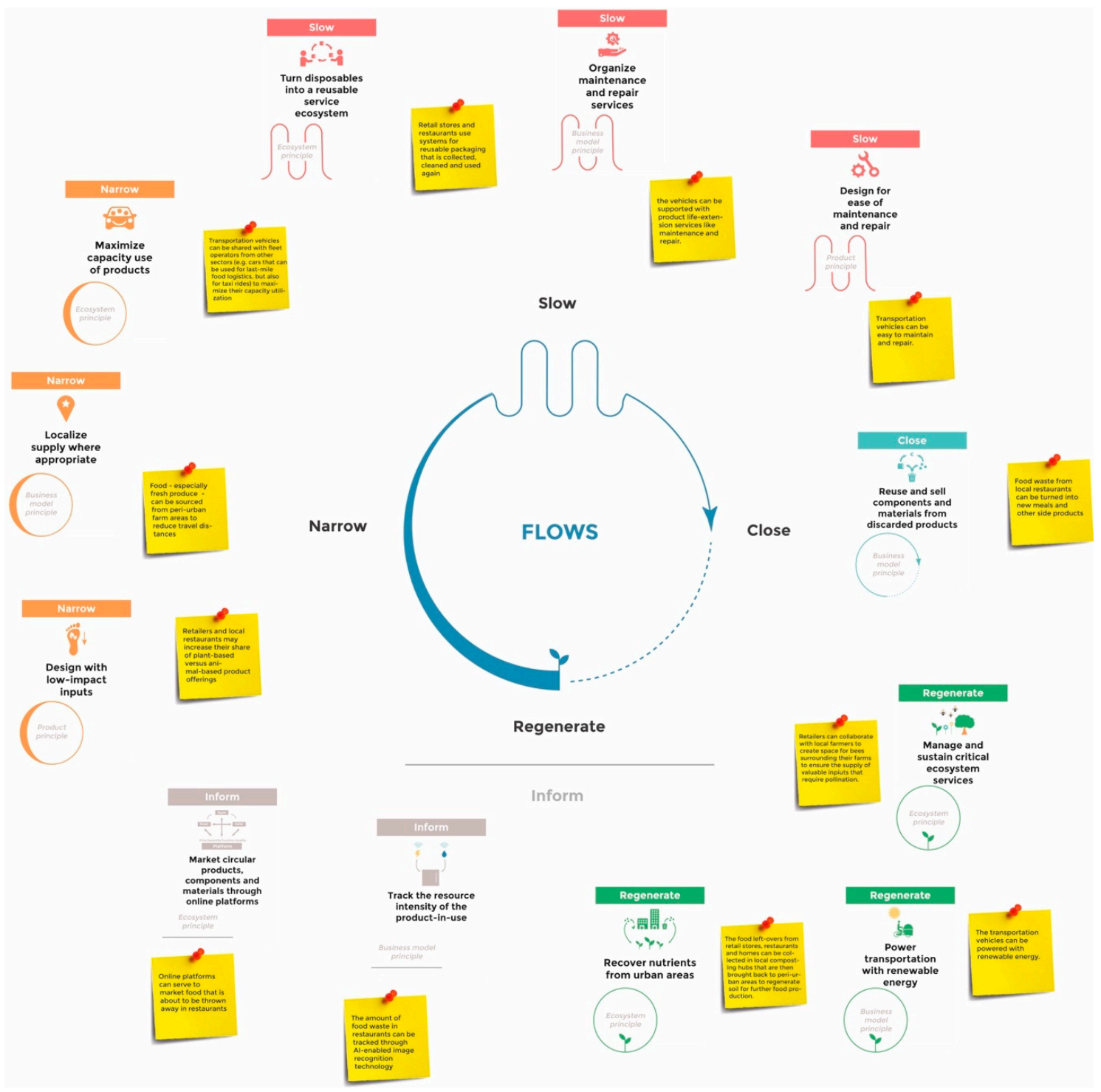

Figure 5. Analyzing and developing the circularity potential of a hypothetical circular food ecosystem.

Based on the evaluations of the 12 workshops, we propose that a session with the Circularity Deck should take about three hours and is best organized in a group of maximum 12 people. Participants should leave a session with a widened ecosystem perspective on circularity, an understanding of their role within that wider ecosystem, as well as ideas on how they may innovate their ecosystem, and whom they need to engage to get their buy-in and commitment. It is essential to have a trained facilitator to lead a workshop session; that is, someone who is familiar with the circular economy, the four strategies, the principles, the practice examples, and the different innovation perspectives (products, business models, ecosystems). The session then includes the following steps:

1. Present the circular economy framework and the five circular strategies (Figure 2). Use an image similar to Figure 5 to give examples of the principles for each strategy in a particular context. Show Figure 1 to explain that there are product, business model and ecosystem principles for each strategy. It is also important to explain how the cards relate to each other. First, some cards 
are similar to each other. This may be because a principle applies to more than one strategy. For example, the 'slowing' principle for products-'design for easy dis- and reassembly' — can also be found as a separate 'closing' principle for products as 'design for easy disassembly at the end of the product's life'. Both cards exist, because design for disassembly to enable easy repair may be different from design for easy disassembly to ensure higher recyclability. Both are important to take into account during circular product design. Another example refers to the two 'slowing' principles for business models: 'provide the product as a service' and 'organize maintenance and repair services'. The former relates to the value proposition and the latter to the value creation and delivery of the circular business model. In addition, cards may relate to each other in all kinds of ways. An example is the 'informing' principle for products: 'design connected products'. This principle may be needed to support the 'narrowing' principle 'enable and incentivize users to consume less'. Another example is the 'narrowing' principle for products: 'design light-weight products', which may support the 'slowing' principle 'provide the product as a service'. In general, analyzing and developing circular innovation ecosystems implies that participants identify the relationships among the cards: to realize when one principle enables another one; and how many cards together can enable circularity to emerge as a systemic property in a given innovation ecosystem.

2. Let the participants define a clear problem or challenge that they want to work on during the session. This can be a specific business context or industry, an existing business model or future circular oriented goals that an organization or several organizations want to work towards.

3. Hand out prints (at least A4) of the circular economy framework (Figure 1) and let people brainstorm for about five minutes how they currently use these strategies to address their problem or challenge. This step is to analyze the current status quo. The output can be captured on post-its.

4. Ask the participants to spend five minutes to think about how they can apply the circular strategies in their context. This step makes sure that people can first generate more open ideas about how they could apply the strategies and prevent that they are influenced by the content of the Circularity Deck. During this step, participants are asked to write on post-its and map them around the circular economy framework.

5. Hand out the Circularity Deck so that the participants can get to know the cards. It might be helpful to pre-select some cards to reduce the overall number of cards that the participants have to go through and to increase the relevance of the cards for a particular context. Not all cards are, for example, relevant to the textile sector.

6. Once they have a basic understanding of the cards, ask participants to analyze if and how the principles can be implemented in their context. The cards can then be put on the table around the framework where each stack of cards belongs. Participants can browse through them and map them around the circular economy framework, similar to how the cards and post-its are mapped around the framework in Figure 5. This exercise results in a circular economy framework that is surrounded by selected cards and post-its. This can then serve to generate and discuss ideas and necessary actions that can lead to higher degrees of circularity.

\subsection{Evaluation and Iterations of the Circularity Deck}

Each workshop experience served to evaluate and improve the Circularity Deck, based on the results (Appendix C) from the feedback forms (Appendix B). Iterations throughout the six professional workshops with 136 evaluations in different settings give confidence that the tool is useful-for entrepreneurs, innovation managers, business managers and designers-to analyze, ideate and develop the circularity potential of innovation ecosystems (average rating: 4.52/5; standard deviation: 0.56 ), and that it is easy to use (average rating: 4.42/5; standard deviation: 0.73). Participants noted, for example, that the Circularity Deck can "reduce complexity", provide a "helicopter view" and "a new perspective", and "ensure that many aspects are considered". After each workshop, the feedback was used to make 
the following changes to the Circularity Deck (Table 2). A figure with some of the cards from the first version can be found in Appendix D.

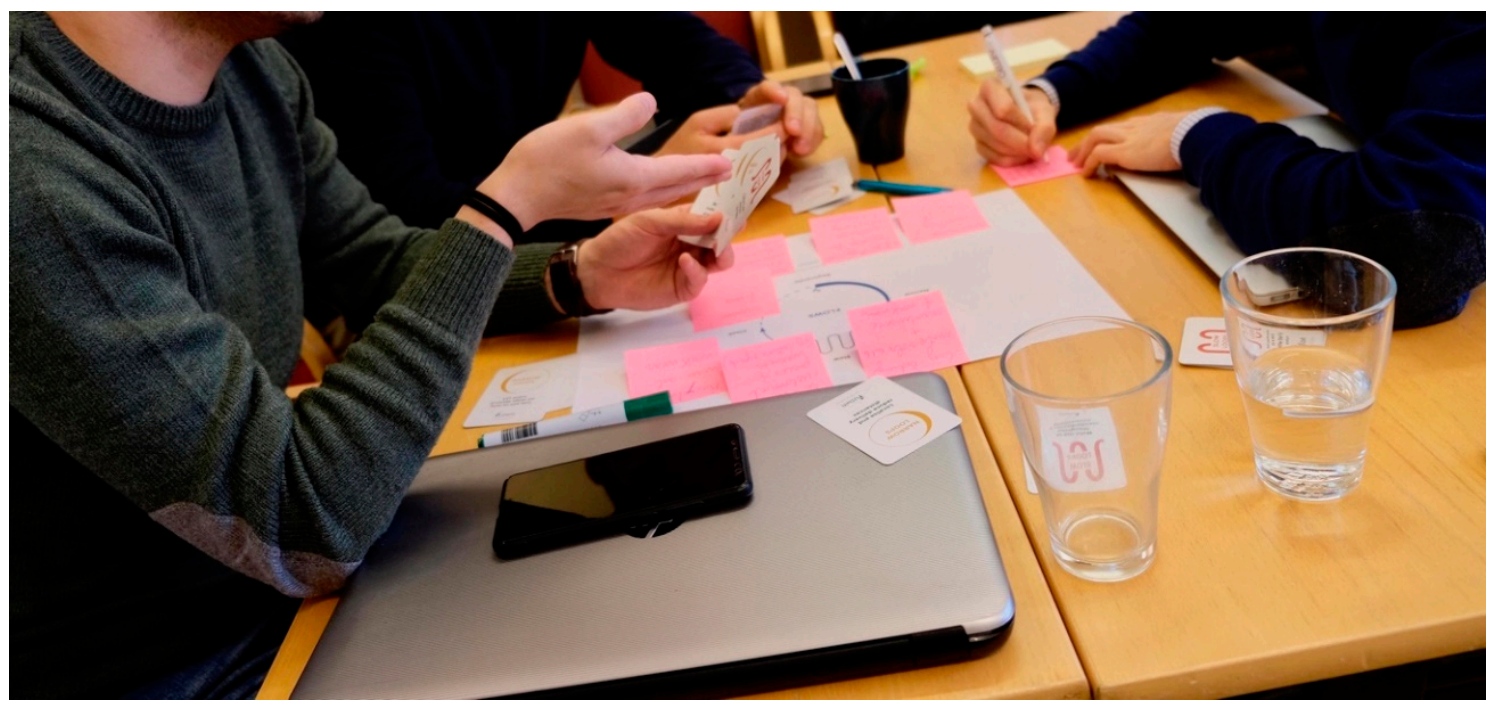

Figure 6. How the Circularity Deck has been used in one of the workshops.

Table 2. The feedback from the workshops and the changes made.

\begin{tabular}{|c|c|c|}
\hline Work-Shop & Feedback & Changes \\
\hline 1 & Clarify principles, add examples & $\begin{array}{l}\text { Rewrote principles for more clarity, researched } \\
\text { and added examples for each principle }\end{array}$ \\
\hline 2 & Get rid of overlapping principles & Revisited principles for more differentiation \\
\hline 3 & $\begin{array}{l}\text { Principles and examples may be } \\
\text { limiting, lacking connections between } \\
\text { the cards, pose principles as questions, } \\
\text { improve quality of the cards }\end{array}$ & $\begin{array}{l}\text { Added } 10 \text { min of brainstorm without the cards, } \\
\text { better explanations on the relationships of the } \\
\text { cards, better quality prints for cards }\end{array}$ \\
\hline 4 & $\begin{array}{l}\text { Address viability of the principles, } \\
\text { conceptual overlap among cards }\end{array}$ & $\begin{array}{l}\text { Revisited principles to better differentiate them, } \\
\text { improved guidance on how to use the cards }\end{array}$ \\
\hline 5 & Translate cards into Dutch & - \\
\hline 6 & $\begin{array}{l}\text { Address overlapping cards, clarify } \\
\text { relationships between cards }\end{array}$ & $\begin{array}{l}\text { Provide better explanations for the conceptual } \\
\text { similarity between cards in the guidance, explain } \\
\text { possible relationships in the guidance }\end{array}$ \\
\hline 7 & $\begin{array}{l}\text { Add new card on design with renewable } \\
\text { materials, make a pre-selection of cards, } \\
\text { give clear instructions, add a 'playing } \\
\text { board' to the cards, make the ecosystem } \\
\text { perspective clearer, change card design, } \\
\text { add cards that explain the strategies }\end{array}$ & $\begin{array}{l}\text { Added new card on 'design with renewable } \\
\text { materials', added the possibility to preselect cards } \\
\text { to the instructions, added instructions on how to } \\
\text { allocate the cards around the framework to better } \\
\text { explain the ecosystem perspective, changed the } \\
\text { card deck design (added a colored top layer) to } \\
\text { make it easier to grasp }\end{array}$ \\
\hline $8 / 9$ & - & - \\
\hline $10 / 11$ & $\begin{array}{l}\text { Include a 'get-to-know the card deck' } \\
\text { phase before starting the ideation, give } \\
\text { more time for the session }\end{array}$ & $\begin{array}{l}\text { Added a step to the instructions to ensure that } \\
\text { the participants have enough time to understand } \\
\text { the card deck, changed the proposed time for a } \\
\text { workshop from two to three hours. }\end{array}$ \\
\hline 12 & $\begin{array}{l}\text { Define a clear problem or challenge at } \\
\text { the beginning of the session }\end{array}$ & $\begin{array}{l}\text { Added a step to the instructions that lets } \\
\text { participants define a clear problem or challenges } \\
\text { that they want to work on during the workshop }\end{array}$ \\
\hline
\end{tabular}


The first version was tested in a workshop with a big health technology company. The session showed that not all principles were clear, so we refined them afterwards. In addition, one participant remarked that examples would be helpful to better understand the principles, which we then included. Another participant remarked that more group work would be better. We took this into account for subsequent workshops.

The second workshop was held with twelve circular startups as part of an incubator program at Impact Hub Amsterdam. Following the workshop, one participant remarked that there was too much overlap among the principles. We therefore revisited the principles, merged similar ones and edited others to better distinguish them from each other.

The third workshop was conducted with staff from a mobility design agency. One participant suggested that the principles and examples may limit people to come up with their own ideas. In subsequent workshops, we therefore gave people some time to first generate their own ideas on how to implement the four circular strategies, and only then distributed the cards with our principles and examples. Another remark was that it was difficult to make connections between the cards: how does, for example, the product principle 'design light-weight products' (narrowing) affect the business model principle 'provide the product as a service'? We used the feedback to better highlight the relationships among the different strategies and principles in the guidance on how to use the cards during the workshop. Another idea that resulted from the feedback was to pose the principles as questions. We decided not to do that to save space on the cards and keep the principles short. Following further feedback, we improved the quality of the cards by editing the text on the cards to improve their readability and developing a professionally printed version.

The fourth workshop was conducted with participants from different small and medium sized enterprises from a province in the North of the Netherlands. One participant noted that the tool missed elements such as cost and performance. We thought about how to integrate a cost perspective to assess the viability of ideas but decided to leave it out of this tool. This decision was made because the purpose of the tool is to analyze, ideate and develop the circularity potential of ecosystems. Assessing business viability comes later, once maps and ideas are documented. Another participant highlighted conceptual overlaps among the principles. We therefore revisited the consistency of the principles once more. Further remarks related to the need for an online version of the Circularity Deck, and better guidance on how to use the cards. We decided to explore the former suggestion in a later stage of this project. The latter was addressed by providing clearer guidance on how to use the deck.

The fifth workshop was held at a large engineering service company in the Dutch construction sector. One participant suggested to translate the card deck into Dutch. We decided to consider this as an 'extra' that can be explored in the future. Other remarks concerned the 'broad interpretation' of circularity, something we intentionally did to let participants understand the broad nature of changes that are needed to transition towards a circular economy.

The sixth workshop was held as part of an international coaching program for 21 entrepreneurs to develop their circular business models. The participants provided positive feedback. Two issues needed to be addressed: the seeming redundancy of some cards and the relationships between the cards. We decided to enhance the briefing before using the cards and the description of how to use the cards to provide more clarity (see Section 4.2).

The seventh workshop took place at the Impact Hub in Hamburg, Germany. Based on the feedback, we added one more card to the 'regenerate' strategy: design with renewable materials'. We also added to the instructions that it may help to make a pre-selection of cards based on the context, to reduce the cognitive load of the cards and make them more applicable to a particular context. We also changed the title of the manuscript, to reflect the various purposes the Circularity Deck can serve: to analyze existing ecosystems, as well as ideate and develop the circularity potential of innovation ecosystems. Lastly, the design of the deck was changed to make the strategies more distinguishable. The final version has a colored top layer that indicates the strategy for easy visibility and the possibility to quickly browse through the cards. 
The eighth workshop was held during a conference in Riga, Latvia and the ninth workshop with a design agency from Helsinki, Finland. The feedback from the participants of both workshops did not include direct recommendations on how to improve the tool.

The tenth and eleventh workshops were held at a university in Espoo, Finland with innovation managers, designers and researchers. One participant suggested to include a step to get to know the cards before the ideation. We included this as a step in the instructions (step 5 in Section 4.2). Again, the participants were overwhelmed with the number of cards that they had to read within a short period of time. Next to the possibility to pre-select cards, we extended the proposed time for a workshop from two to three hours.

The twelfth workshop took place at a university in Lappeenranta, Finland. At the beginning of the session, we asked the group to split in two and have a challenge owner in each group who explains the challenge to the rest of the group. One group worked on the circular economy of the city of Lappeenranta with the circular economy director of the municipality, the other on the circularity of a welding company whose chairman and environmental manager were present. One participant confirmed in the feedback form that defining a clear problem or challenge is crucial at the beginning of the session. We included this in the instructions (step 2 in Section 4.2).

\section{Discussion}

Our study makes two main contributions to the circular economy research and practice. First, as a theoretical contribution, it proposes a novel way to analyze circular strategies and principles to provide an ecosystem perspective on the circular economy. The ecosystem perspective consists of (1) a number of explicit ecosystem principles for narrowing, slowing, closing, regenerating and informing material and energy flows, (2) a number of product, business model and ecosystem principles that-when combined-enable firms to take an ecosystem perspective on the circular economy and work towards higher circularity. Second, as a practical contribution, our study provides a well-researched and tested tool that can be used to analyze, ideate and develop the circularity potential of innovation ecosystems in a given context. It thereby makes the analysis from the literature and practice review useful for practitioners, which is an important step to close the theory-practice gap of organizational research [41]. In the following, we discuss both contributions and their limitations.

As a theoretical contribution, this study adds an ecosystem perspective to the existing tools and approaches that have focused on products and business models $[26,27,166,167]$. It thereby proposes an analytical approach for firms to better understand the systemic nature of circularity. In addition, this approach helps to uncover conceptual ambiguities in existing frameworks. Throughout the research for this paper, we noticed that several frameworks used in practice and research are not clear on the type of circular economy strategy that they pursue. This is the case, for example, with the RESOLVE framework proposed by the Ellen MacArthur Foundation [4]. It contains principles such as 'virtualize', 'share', 'optimize' and 'exchange'. They provide a general direction of what to do but are ambiguous regarding their intended influence on the circularity or sustainability of material and energy flows. 'Maximize excess capacity' ('share') as a principle, for example, does not have environmental benefits per se. It needs to be supported by other principles like 'design for easy maintenance and repair' (product principle for 'slowing'), 'organize maintenance and repair services' (business model principle for 'slowing'), or 'power transport with renewable energy' (business model principle for 'regenerating') [75]. This study supports the development of circular ecosystems that do not assume that principles like 'virtualize' or 'share' are good from an environmental perspective per se. Even though the Circularity Deck aims at 'better ecosystems', it is important to assess the environmental impacts of the proposed ideas and actions that result from its use. This assessment is needed to understand which principles and strategies have the highest potential to decrease environmental impacts in a given context. An assessment is important, because the impact reduction potential of any solution is not obvious. For example, life-cycle assessments of aluminum cans have shown that a higher cradle to cradle certification does not automatically translate to a lower environmental impact [168]. 
As a practical contribution, this study develops the Circularity Deck: a practitioner-focused tool for circular ecosystem innovation. This has led to some findings on how to improve circular oriented innovation tools. Previous research has emphasized, for example, the need to define clear learning outcomes and goals for a tool, define its intended user group, and to incorporate 'circularity checks' $[27,167]$. We add three findings to this to provide further guidance for future tool development: (1) clear and concise descriptions and examples can help the participants to understand the tool content and concepts better and faster, (2) participants may benefit from an exercise without a tool, to be free from the possible constraints that it imposes, and to reveal its power once it is used, (3) a tool is most useful when actively facilitated by an expert who is familiar with its background concepts.

It is important to highlight the limitations of this study. First, we neither claim that the underlying review of the Circularity Deck is complete, nor that it captures all relevant principles. Rather, the contribution lies in proposing a framework of circular strategies (narrow, slow, close, regenerate, inform) and innovation perspectives (product, business model and ecosystem) that can be used by future research to edit and extend the set of principles that resulted from the review of this study. Efforts to innovate towards sustainability constantly evolve, and addressing wicked issues like sustainability has no clear starting or end point [169]. It is therefore important to acknowledge that the research output of this study does not present a fixed result, but rather a starting point, or another research input, for further research in different contexts. Second, it is important to highlight that the tool has been tested in a limited number of contexts. While we are confident about its usefulness and ease of use for entrepreneurs, innovation managers, business managers and designers, it is important to acknowledge that the tests were conducted in developed economy contexts, i.e., in the Netherlands, Sweden, Germany, Latvia and Finland. Yet, it should be noted that the participants and facilitators came from diverse backgrounds, also from outside of these countries. Third, it is important to recognize that the tool proposed here does not incorporate social and institutional dimensions of the circular economy. This includes, for example, the need to price carbon emissions or other forms of externalities, as well as the need to explore more participatory and redistributive forms of government that can safeguard and improve the quality of work and equity within an emerging circular economy [170]. We suggest that future research may include a set of social and institutional principles to complement the principles proposed in this study.

\section{Conclusions}

This study proposes the Circularity Deck: a tool and approach to analyze, ideate and develop the circularity potential of innovation ecosystems. The tool is based on a literature and practice review of recent circular economy strategies and principles. The principles are organized according to the perspective that is needed to implement it: a product, business model, or ecosystem perspective. We conclude on the review that an ecosystem perspective on a circular economy is both needed and useful for firms to capture circularity as a systemic property. The Circularity Deck-a practitioner-focused tool-helped to make the review results useful. The tool has been tested for its 'perceived usefulness' and 'ease of use' in 12 workshops with 136 participants from 62 firms to ensure that the Circularity Deck has practical value. Based on these iterations and an average rating of $4.52 / 5$ on usefulness and an average rating of $4.42 / 5$, we conclude that the tool is useful and easy to use for entrepreneurs, innovation managers, business managers and designers. Future research is needed to continuously update the tool with new principles examples, and, more generally, to identify more principles to narrow, slow, close, regenerate and inform the material and energy flows that are associated with business activity in the pursuit of an environmentally sustainable circular economy. Furthermore, there is value for future research to use the approach proposed in this study to develop sector-specific versions of the Circularity Deck, most notably for sectors such as mobility, food and construction, due to their high global life-cycle environmental impacts.

Author Contributions: conceptualization, J.K. and N.B.; methodology, J.K., N.B. and E.J.H.; formal analysis, J.K.; investigation, J.K.; data curation, J.K.; writing—original draft preparation, J.K.; writing-review and editing, J.K., 
N.B. and E.J.H.; visualization, J.K.; supervision, N.B. and E.J.H.; funding acquisition, N.B. All authors have read and agreed to the published version of the manuscript.

Funding: This research was funded by the Horizon 2020 Program of the European Commission, grant number 721909.

Acknowledgments: This work was made possible by the Marie Sklodowska-Curie Innovative Training Network "Circ€uit" - Circular European Economy Innovative Training Network, within the Horizon 2020 Program of the European Commission (grant agreement number: 721909). The authors gratefully acknowledge the support of the European Commission and the contributions of partners in this project.

Conflicts of Interest: The authors declare no conflict of interest.

\section{Appendix A}

Table A1. The search strings used and the articles retrieved from the literature review.

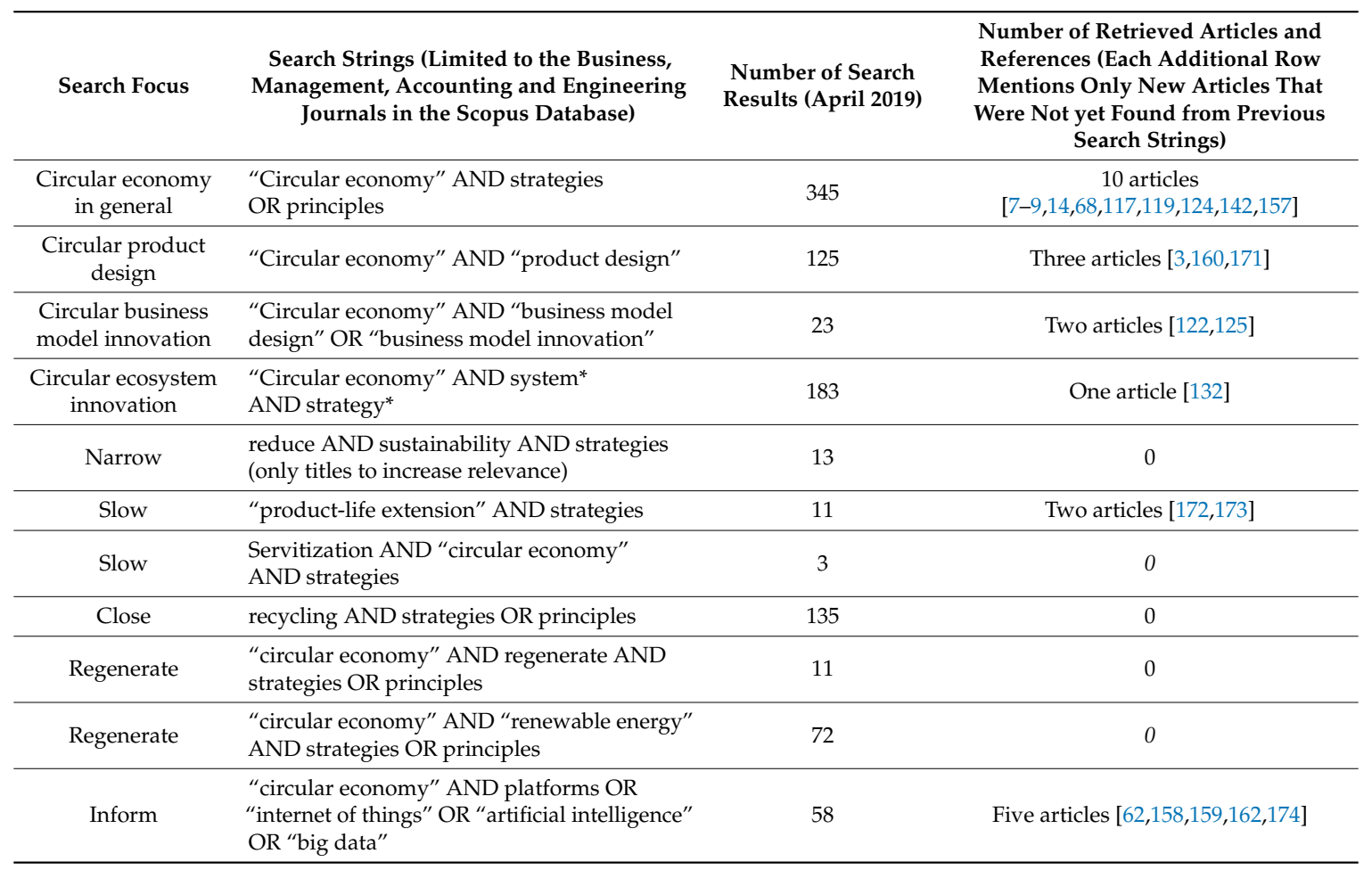




\section{Appendix B}

\section{FEEDBACK FORM}

The purpose of the Circularity Deck is to learn about the circular economy and the strategies and principles needed to transition innovation ecosystems towards circularity.

\section{Circularity Deck}

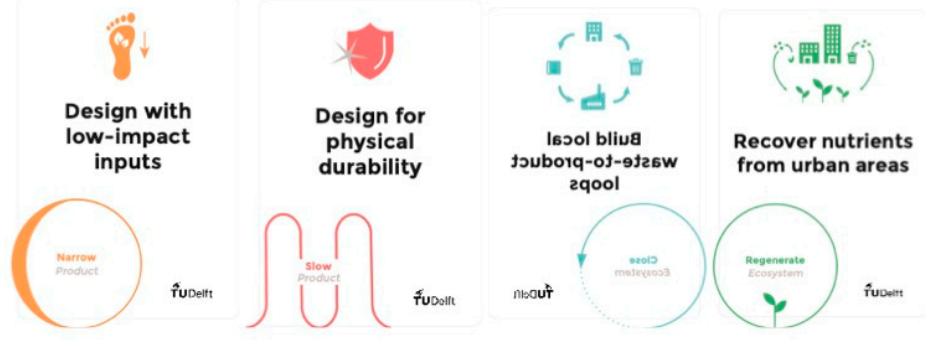

1. The Circularity Deck was useful to address the purpose stated above:

$\begin{array}{llllllll} & 0 & 1 & 2 & 3 & 4 & 5 & \\ \text { Do not agree at all } & 0 & 0 & 0 & 0 & 0 & 0 & \text { Fully agree }\end{array}$

Please explain your answer (What was most useful? What was less useful? Why?)

2. The Circularity Deck was easy to understand / use:

$\begin{array}{llllllll} & 0 & 1 & 2 & 3 & 4 & 5 & \\ \text { Do not agree at all } & 0 & 0 & 0 & 0 & 0 & 0 & \text { Fully agree }\end{array}$

Please explain your answer (What was easy? What was difficult? Why?)

Figure A1. The form used to evaluate the ease of use and usefulness of the Circularity Deck. 


\section{Appendix C}

Table A2. The workshop feedback: rating and qualitative feedback.

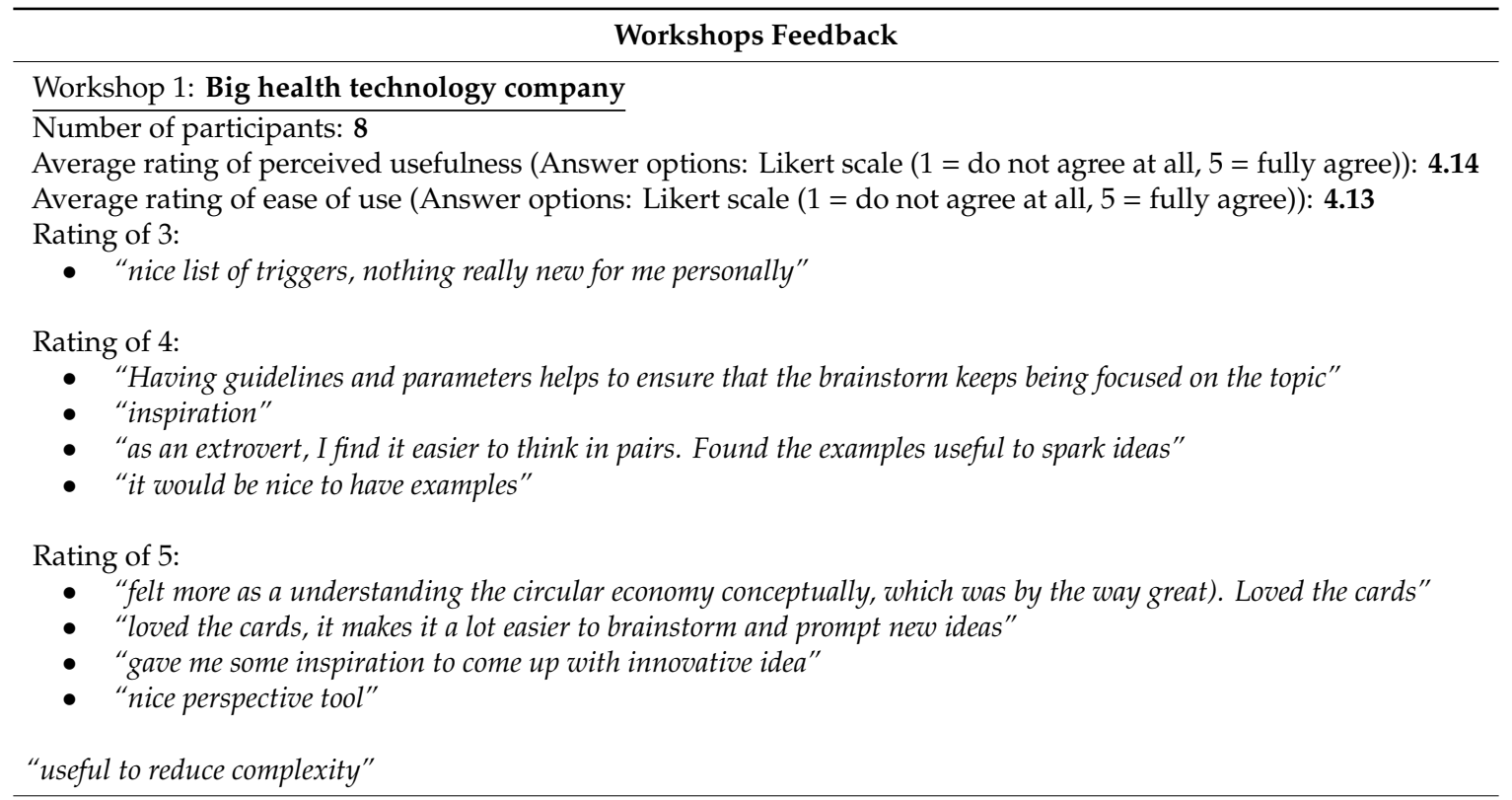

Workshop 2: Twelve circular startups during the 'Investment Ready Programme' of Impact Hub

Number of participants: 11

Average rating of perceived usefulness: 4.55

Average rating of ease of use: $\mathbf{4 . 5 5}$

Rating of 4:

- "The different loops $\rightarrow$ tools to explain your circularity, the cards $\rightarrow$ good examples of companies which produced something"

- "Good theoretical substantiations, we could relate it easily to our product"

- "It was very practical for us"

- "Some topics were not typically for a product"

- "Very useful to pitch your circularity and brainstorm improvements!"

- "At the start the purpose was a bit unclear but once we realized they were suggestions it made for an easy-going discussion on things that can be done"

- "Like I wrote above, at the start I didn't understand what the cards were for. Sometimes the examples are a bit confusing, probably because circularity is different for a food company than for a machine building company"

- "Useful: it sharpens what you already do, what you will never do and inspires next steps to optimize the impact of the business, I missed the cards about how we are closing loops: presumption: make people buy things that will change their behaviour in a positive way (induction cooking)"

- "Too much overlap in cards, some are too similar"

- "Requires some effort to understand how the example cards would translate into an idea for your business"

Rating of 5:

- "Insights in all different options, we are so into our daily work that an exhaustive list is of great use, helicopter view!"

- "Examples work really good, I do think it is fit for professionals and for people who have a basic understanding of a circular economy"

- "Very clear and helpful in giving ideas"

- "Simple and clear, liked the model with the different loops, thanks!"

- "It is nice to see where you stand with your products in the loops and where you can improve the loops"

- "I loved your cards, not too much info on them and it was well built up to our final assignment"

- "The text on the cards was clear, nice to have an example on each card"

- "It sparks ideas"

- "The explanations on the back really worked"

- "Provides clarity"

- "Written in a clear way which sparks ideas"

- "Note: circularity is interpreted in 'the resource way'. What about social inclusion/impact?"

- "Really helps to generate ideas, the cards are cool" 
Table A2. Cont.

\section{Workshops Feedback}

Workshop 3: Mobility design agency

Number of participants: 6

Average rating of perceived usefulness: 4.5

Average rating of ease of use: 4.83

Rating of 3:

- "Good starting point, nice to have real-world examples, although this might also steer/limit a bit too much, maybe asking basic questions could also be a good way to get people thinking"

Rating of 4:

- "The cards ensure that many different aspects are considered in the brainstorm. The 'regenerate' cards were more difficult but that can be specific to this project"

- "Ideas from each strategy were kept distinct and separate, would be useful to integrate/cross-pollinate"

- "Understandable, but maybe feels slightly 'pragmatic', "businessy""

Rating of 5:

- "+ narrowing it down to smaller questions is helpful, - maybe more in question form (how, why, when etc)"

- "How to narrow it down?"

- "Yes, easy to use, good outcomes"

- "I didn't read any of the stories on the card, they were pretty self-explanatory. The presence of these cue cards make you think of stuff that can be pretty obvious but quickly overseen"

- "The product-design ones were easiest, there were also quite a few that just needed a "yes" (lets do that), cards should be a bit thicker for re-use"

- "Interesting to focus on specific aspects, next phase as a group phase was good to cluster ideas, the outcome? A concept profile."

- "Clear with the examples"

- "Fueled a lot of ideas on different levels"

- "The cards are like a morphological map tool, for holistic ideas might need a $2^{\text {nd }}$ tool or step"

- "Maybe condense or highlight items in the text (quicker to read)"

Workshop 4: Open workshop with 21 participants from different firms of the 'Provincie Noord Holland' at Impact Hub in Amsterdam

Number of participants: 21

Average rating of perceived usefulness: 4.52

Average rating of ease of use: 4.29

Rating of 3:

- "I think if people are not already doing/practicing then it will sometimes not be clear - I can try out toothank you!"

- "New to me, so need to adopt"

Rating of 4 :

- "I really liked the simplified approach to start creating circular models"

- "I am now more curious about the next steps of this framework. As cost and performance are as important as environmental friendliness, it would be good to see how you evaluate a business models' financial feasibility"

- "Good to know about narrow, slow, regenerate ..., connect with other's ideas"

- "Message is clear, but a lot of things were undiscussed"

- "The examples reinforced the 4 concepts, and had a wide range of inspirational stories"

- "The subject matter was covered very broadly so it felt all bases were covered. More instruction on the idea selection phase would be good"

- "Different angles and ideas inspire, one table missed the 'human' element in the examples, how to attract/involve others? , importance of communication, giving experiences"

- "Generally very good, but some related ideas were touched on in different types of loops"

- "Good examples, a lot of overlap, sometimes confusing"

- "Clear"

- "You have the circle in the powerpoint maybe also keep showing the examples so you know what it is (I am old and forget quickly)"

- "New perspective"

- "The examples make it very clear"

- "It was good for a start to grasp the concept of circularity"

- "The more knowledge about circularity you have, the more difficult the use of the deck"

- "It helps to kick-start the thinking process and mindset"

- "When it was initially introduced, I was somewhat confused. The cards helped a lot." 
Table A2. Cont.

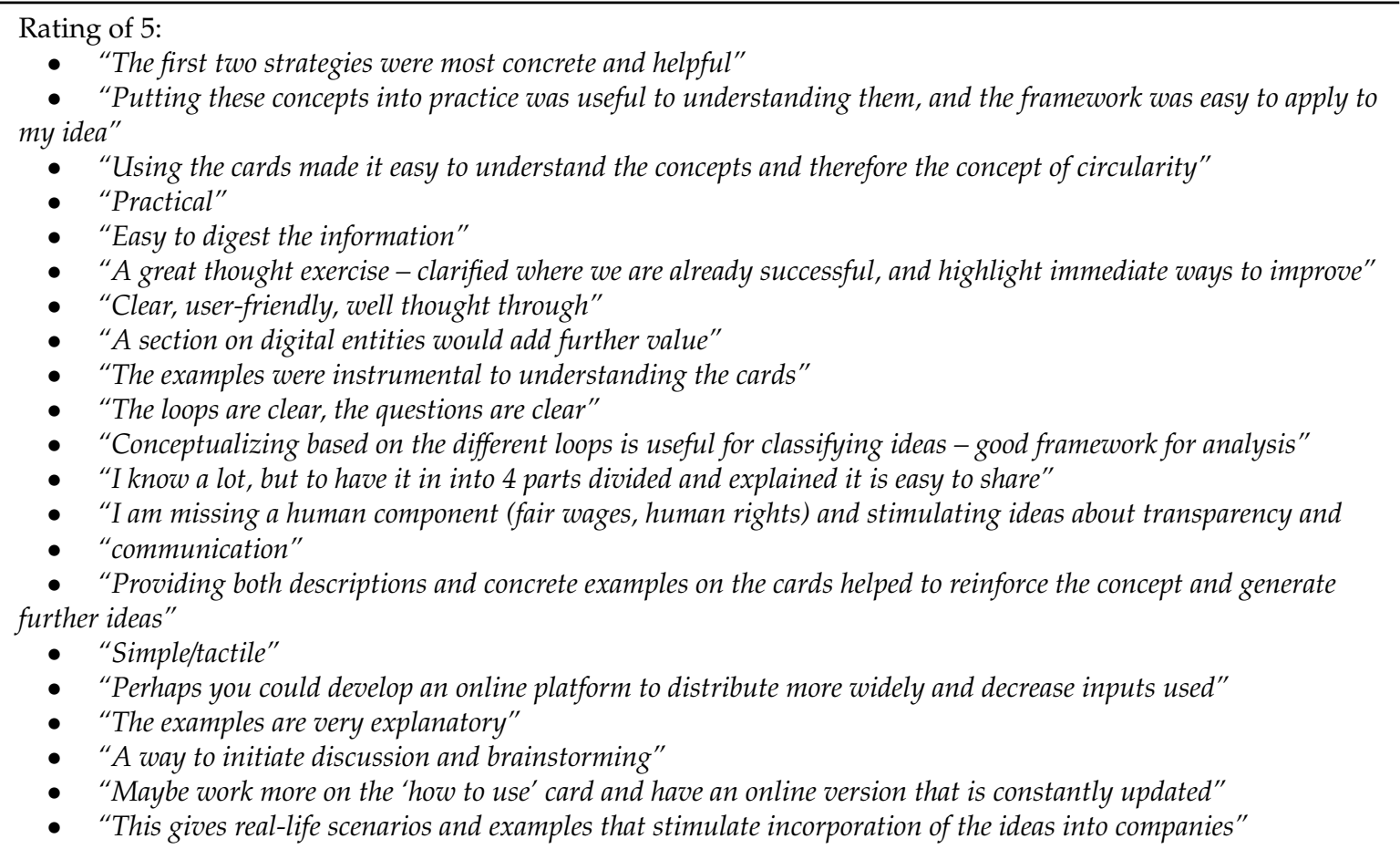

Workshop 5: Workshop with a big civil engineering service company

Number of participants: 5

Average rating of perceived usefulness: 4

Average rating of ease of use: $\mathbf{3 . 6}$

Rating of 2:

- "I would use the Dutch language"

Rating of 3:

- "Gives ideas of possibilities"

- "Circularity is interpreted very broadly"

- "Well-described examples, some of which are very debatable"

Rating of 4:

- "It was useful, with many obvious examples, but it helped"

- "It was easy to use and helped generate ideas"

- "Useful because it was inspiring and it gave direction on the broad concept of circularity"

Rating of 5:

- "Gives a broad view of the concept and concrete ideas on what could be done"

- "Well categorized and in short bits well explained on the back side"

Workshop 6: Open workshop with 21 participants in Sweden as part of an international coaching program to develop their circular business models

Number of participants: 21

Average rating of perceived usefulness: 4.79

Average rating of ease of use: $\mathbf{4 . 2 4}$

Rating of 3:

- "At first I didn't know where to start reading the cards but I found the examples very useful. The cards were very useful at the end"

- "Easy to find solutions in some steps, hard to find a solution that covers all steps, deck: many of the cards are redundant referring to the same concepts, but still good for examples" 
Table A2. Cont.

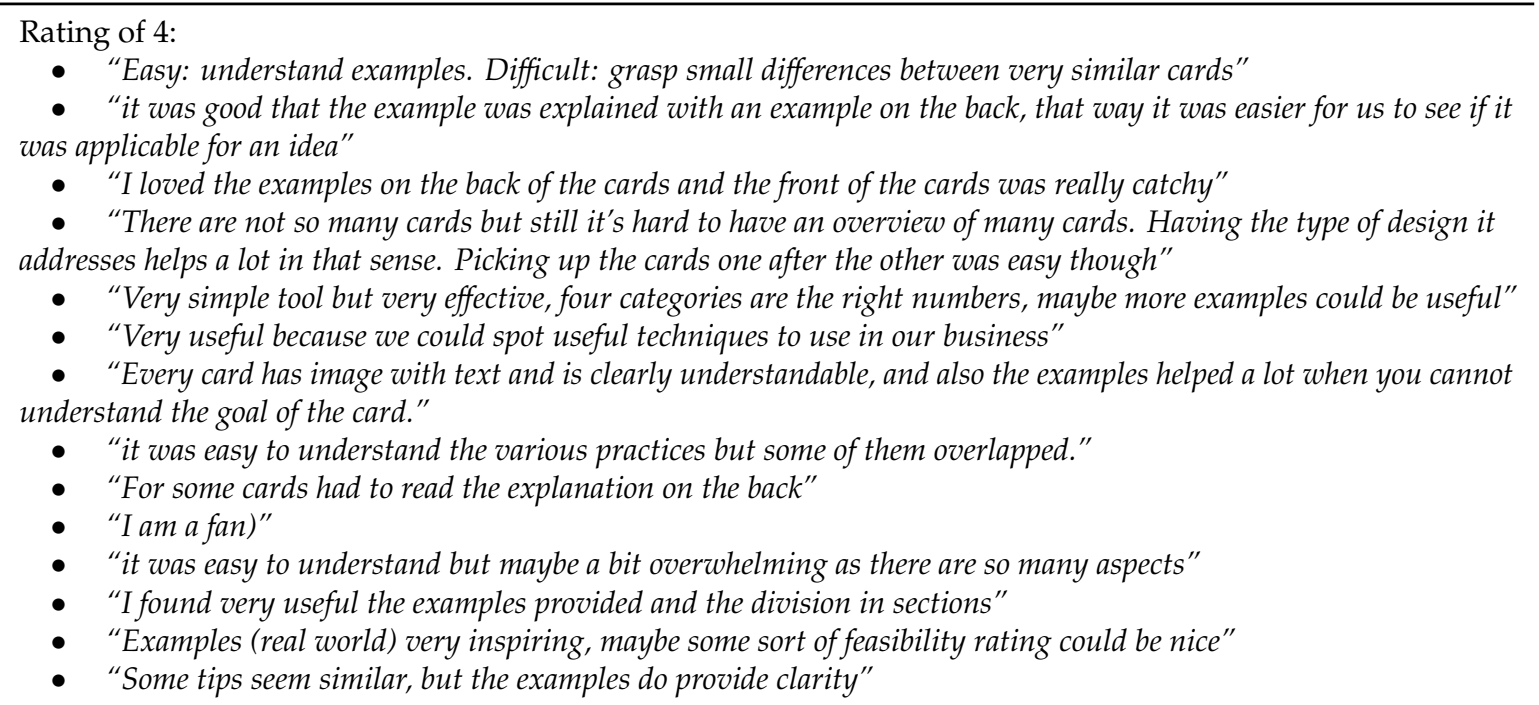

Rating of 5:

- "Thinking about a section (e.g., regenerate) that we excluded without thinking twice. Less useful: time too short"

- "It gave a lot of inspiration strategies we hadn't thought about, especially the 'inform' cards"

- "It mentions several strategies and explains them. Gives new ideas"

- "Example and explanation on the back side was very useful"

- "Separation into different categories makes it easy"

- "Provide an overview of all potential strategies to be combined which do not automatically come to mind."

- "Easy to read and place into context thanks to the examples"

- "Cards were easy to manipulate and place on the desk"

- "Well-colored which makes it easy to visualize"

- "The cards helped us to narrow our ideas and to improve the circular aspect of it. The inform and slow cards were particularly useful in our case"

- "Concrete and practical examples in very concise text. Helped in divergent thinking, and asking questions about the bigger picture"

- "workshop was super practical, fantastic example triggers for ideation"

- "good imagination for all possible strategies that could be applied towards a CE. Very clear and concrete way to explain what CE means, nice to have real examples"

- "Clear with explanations and examples, difficult sometimes to define difference between cards"

- "Lots of different strategies, clear explanations and examples"

- "Practical examples, clear and simple explanations, not always clear what the strategy is without explanation"

- "Helped with statement and to explore broader shape of idea. Cannot be used for all types of business"

- "It gives a different perspective in your business idea, provides original examples"

- "Everything was clear. It's nice that on one side you have the idea and on the other the examples to explain it in kore detail"

- "The different strategies and principles were presented in the cards in a clear and specific way - not too complex or broad vague concepts The variety helps a lot"

- "Very complete range of cards covering all aspects of business, the perfect tool for a circular transformation workshop"

- "it was very helpful to think outside the box and to consider a variety of different aspects"

- "it's useful to split the cycle in several parts in order to focus on them separately, for sure the most usable are the slow and close parts. Sometimes solutions involve several parts, some others involve single steps which makes some of them difficult to integrate fully"

- "it was easy due to the examples provided and the summarizing sentence"

- "I am already familiar with most principles, but to see them in the narrow-slow-close-regenerate structure is helpful to get a clear view on separate aspects and the examples on the back are refreshing"

- "Category and icons and examples" 
Table A2. Cont.

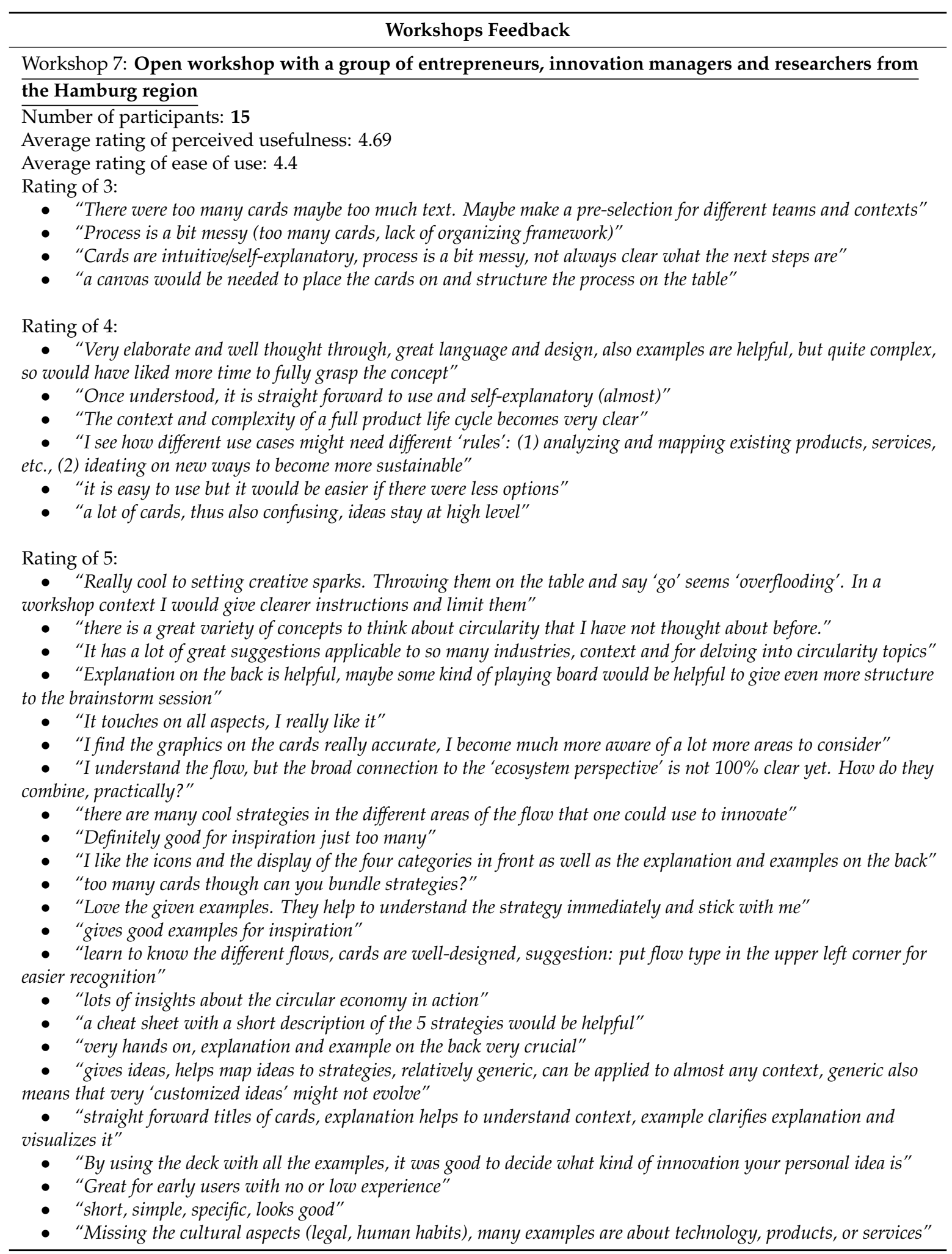


Table A2. Cont.

\section{Workshops Feedback}

Workshop 8: Open workshop with a group of entrepreneurs and innovation managers from Riga, Latvia

Number of participants: 18

Average rating of perceived usefulness: 4.67

Average rating of ease of use: 4.61

Rating of 3:

- "Need a bit more time to get used to it, if the case study is not in your core competence circle"

Rating of 4:

- "Everything starts with structure"

- "If you are able to think out of the box you'll have no problem using this"

- "for us, it was just a repeating of existing knowledge, brainstorming"

- "lots of reading and writing but yes, it is very easy"

- "good tool for initiating conversation and spreading ideas"

- "Useful to a degree because for more technical challenges it might require higher degree of knowledge/ideas"

- The tool was partially hard to understand at first, but when you start using it, you get it"

- "information can be understood in context and associated"

- "no, it's a bit difficult to use, because in ordinary life you are focused on your own perspective"

- "helps to generate new ideas and ways how to achieve a particular goal"

- "By making new implementation you take someone's bread and butter away"

- "gives more questions than provides answers, but new questions lead to more studies"

Rating of 5:

- "The cards and the scheme give a universal approach on how to use and pitch circularity in different areas"

- "I got the idea very quickly"

- "it does help us to dive in and understand the situation and root cause of the problem, however in some cases there is a lack of info for this particular problem"

- "it is easy to use, because it is understandable, you can use your thoughts, you brainstorm, listen to others, widen your vision and perspective"

- "cards broaden perspective and point of view. They make you think outside everyday situations and make adjustments to decision making to think long term"

- "very handy, easy to understand, great examples"

- "it has broadened my perspective about circular economy and life cycle for products and services, thank you guys for an amazing workshop"

- "Haven't worked with this before, gives new perspective"

- "It takes time to understand each card, but still it's easy to use"

- "A bit hard in the short time to see the differences between the terms narrow, slow, etc."

- "would be easier if team members are in the field. And we should have narrowed the problem. More time was needed"

- "It helps to address problems in classified way"

- "Pretty straight forward"

- "I was able to put things in a more practical perspective"

- "I liked the idea of dividing the possibilities into four topics"

- "It is easy and understandable, so refreshing sometimes to see your problem from a different angle, even in non-sustainable product can be found something to make it greener. The workshop was interesting and resourceful"

- The tool was quite useful as it helped to generate a lot of different ideas for any specific project"

- "it is good that examples are given in cards"

- "tools give bigger perspective in circular idea to resolve problem"

- "idea of circles and cards are great to assess different goals in different stages of the circle"

- "Great activity, helped to generate ideas"

- "Great to understand how to implement a circular economy"

- Tools help to generate new ideas, great tool and workshop!"

- "cards help structure areas of improvement"

- "Cards are intuitive and easy to understand" 
Table A2. Cont.

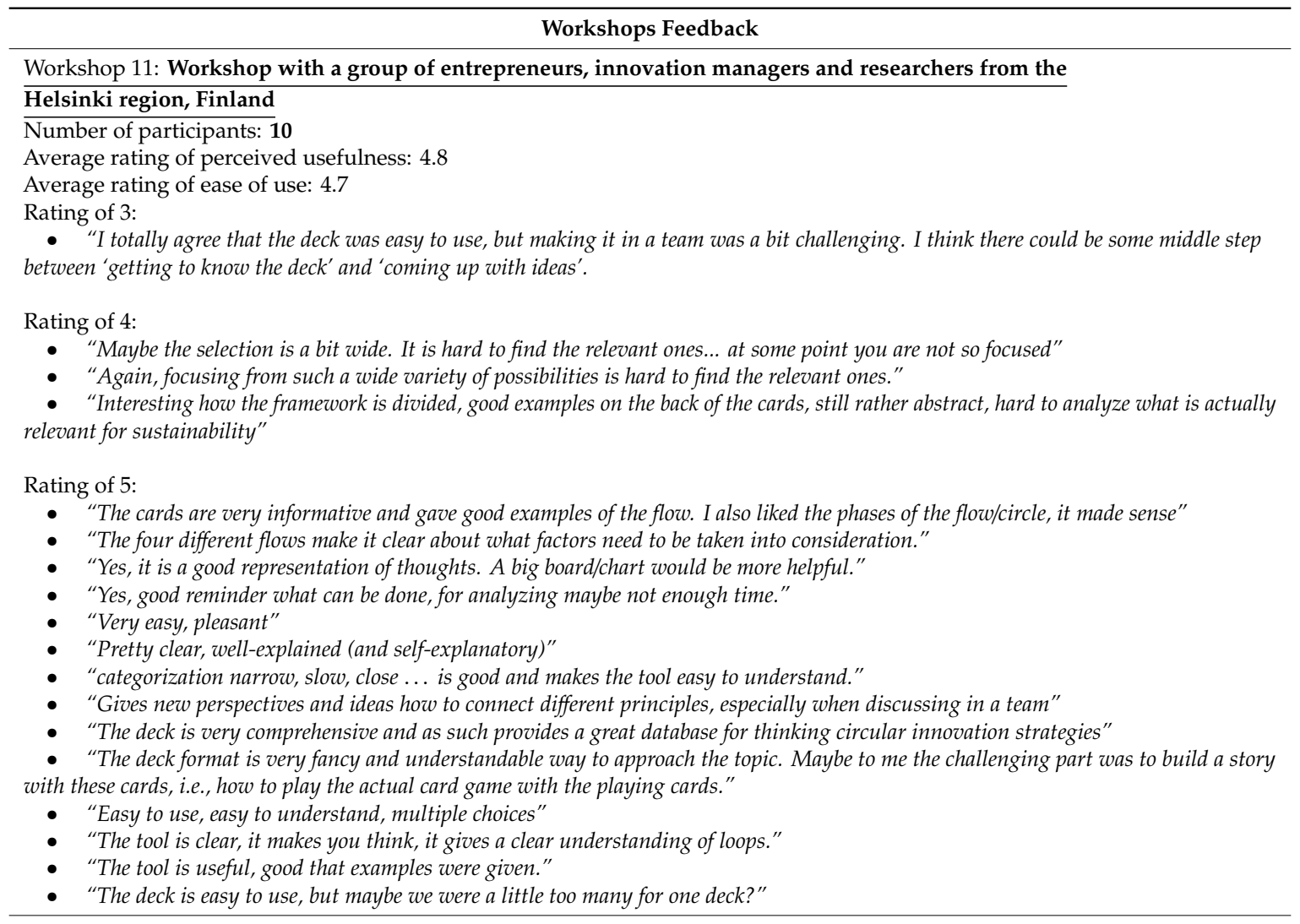

Workshop 12: Workshop with a group of innovation managers and researchers from the Lappeenranta region, Finland

Number of participants: 10

Average rating of perceived usefulness: 4.7

Average rating of ease of use: 4.7

Rating of 3:

- Definition of problems brings more explanatory power to the cards, strict definition first!"

Rating of 4:

- "There are quite a lot of cards, in a limited time frame that is a problem."

- "Needs a concrete business case, without it it will become quite ambiguous what we are doing."

- "The tool is easy and understandable to use but also in some cases and problems it needs more clarification."

- "The tool is easy but some cards are difficult."

Rating of 5:

- "The problem was not a pure business case, but the cards still provided nice starting points to the discussion."

- "Fairly easy, although narrowing down was a bit challenging, as there are so many cards."

- "Easy tool to generate a lot of ideas."

- "Gamification and group spirit works!"

- "Very comprehensive approach, easy to start ideating based on the cards. The explanations and examples on the backside were super. The only challenge is thinking outside the box, or outside the cards, rather."

- "Easy, comfortable, fun. There were a lot of cards so difficult to choose focus."

- "The point of the cards is to serve as a double-checking list of the general aspects and to facilitate associations and creativity"

- "How useful simple keywords/symbols can be to create relevant ideas, when first problem framed, improving, perhaps through discussion."

- "A thousand of ideas."

- "Well suited, easy going, promotes creativity"

- "There is a clear concept of CE, a lot of cards in the deck reflecting the CE in action."

- "It gets the discussion going, sparks new ideas, is structured into five categories, it is easy to point out the responsible functions and capacity. I think it is great to bring ideas to the table and ideate."

- "The explanations and examples are helpful and easy to understand."

- "Soooo many perspectives to consider that any one homogeneous group cannot come up with."

- "Different aspects and ideas, so your mind is not too narrow, e.g., you have open mind for new ideas."

- "It gives a holistic view on circular strategies and works well in that purpose."

- Yes it is easy once you get going. An introduction in the beginning is needed however."

- "Many angles I hadn't thought about, gives you new perspectives."

- "The amount of ideas generated was surprising. A lot of ideas!"

- "Broad examples, helps understanding" 


\section{Appendix D}
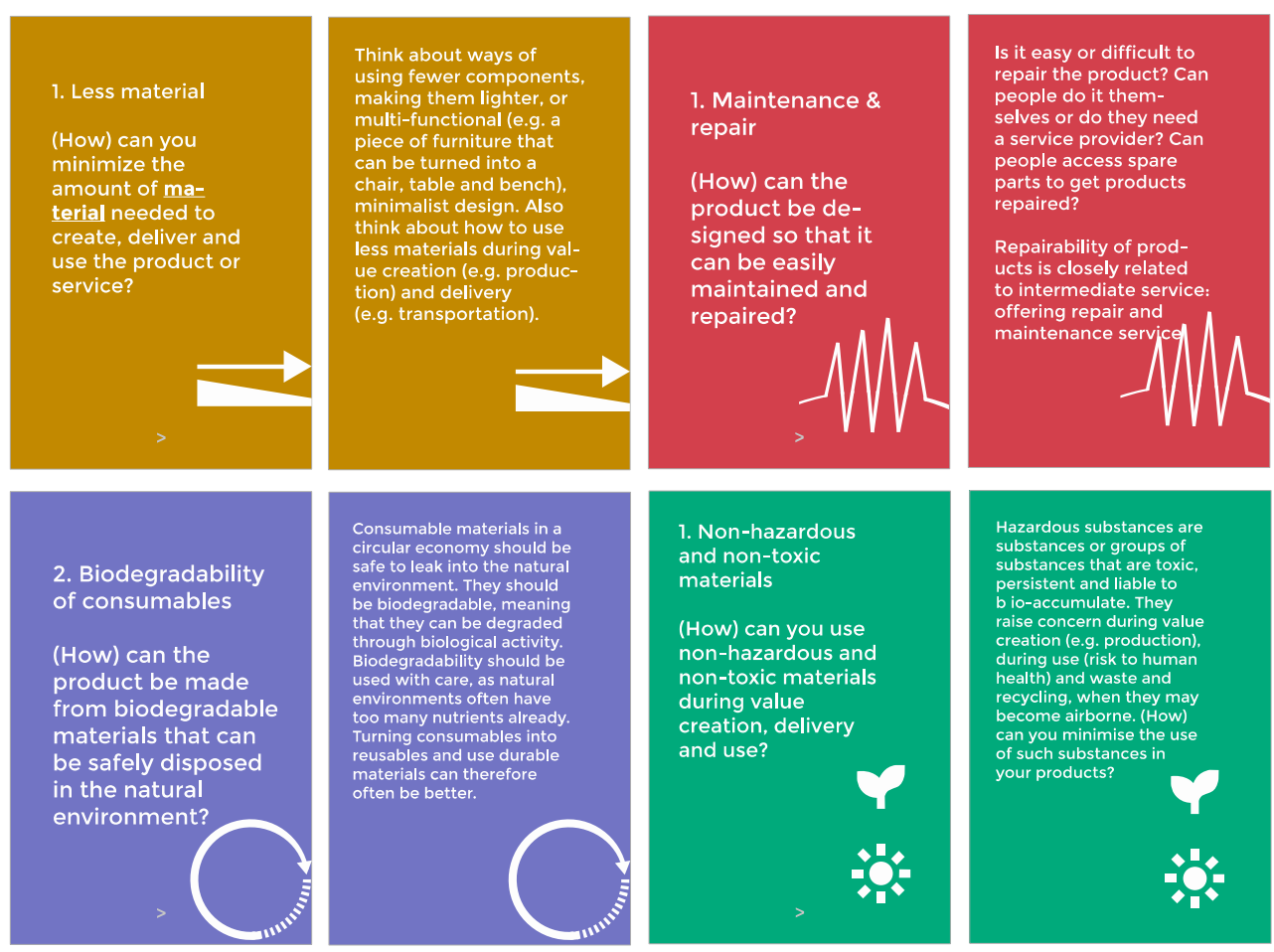

Figure A2. Some example cards from the first version of the Circularity Deck.

\section{References}

1. Blomsma, F.; Brennan, G. The Emergence of Circular Economy: A New Framing Around Prolonging Resource Productivity. J. Ind. Ecol. 2017, 21, 603-614. [CrossRef]

2. Geissdoerfer, M.; Savaget, P.; Bocken, N.M.P.; Hultink, E.J. The Circular Economy—A new sustainability paradigm? J. Clean. Prod. 2017, 143, 757-768. [CrossRef]

3. Bocken, N.M.P.; Bakker, C.; Pauw, I. De Product design and business model strategies for a circular economy. J. Ind. Prod. Eng. 2016, 1015, 20.

4. EMF Growth within: A Circular Economy Vision for a Competitive Europe; Ellen MacArthur Foundation: Cowes, UK, 2015; p. 100.

5. McDonough, W.; Braungart, M. Cradle to Cradle: Remaking the Way We Make Things; North Point Press: New York, NY, USA, 2002; p. 193.

6. De los Rios, I.C.; Charnley, F.J.S. Skills and capabilities for a sustainable and circular economy: The changing role of design. J. Clean. Prod. 2017, 160, 109-122. [CrossRef]

7. Walls, J.L.; Paquin, R.L. Organizational Perspectives of Industrial Symbiosis: A Review and Synthesis. Organ. Environ. 2015, 28, 32-53. [CrossRef]

8. Moreno, M.; De los Rios, C.; Rowe, Z.; Charnley, F. A conceptual framework for circular design. Sustainability 2016, 8, 937. [CrossRef]

9. Mont, O. Innovative approaches to optimising design and use of durable consumer goods. Int. J. Prod. Dev. 2008, 6, 227-250. [CrossRef]

10. Govindan, K.; Jafarian, A.; Khodaverdi, R.; Devika, K. Two-echelon multiple-vehicle location-routing problem with time windows for optimization of sustainable supply chain network of perishable food. Int. J. Prod. Econ. 2014, 152, 9-28. [CrossRef]

11. Pigosso, D.C.A.; Zanette, E.T.; Filho, A.G.; Ometto, A.R.; Rozenfeld, H. Ecodesign methods focused on remanufacturing. J. Clean. Prod. 2010, 18, 21-31. [CrossRef]

12. Elia, V.; Gnoni, M.G.; Tornese, F. Measuring circular economy strategies through index methods: A critical analysis. J. Clean. Prod. 2016, 142, 2741-2751. [CrossRef] 
13. Urbinati, A.; Chiaroni, D.; Chiesa, V. Towards a new taxonomy of circular economy business models. J. Clean. Prod. 2017, 168, 487-498. [CrossRef]

14. Bakker, C.; Wang, F.; Huisman, J.; Den Hollander, M. Products that go round: Exploring product life extension through design. J. Clean. Prod. 2014, 69, 10-16. [CrossRef]

15. Ghisellini, P.; Cialani, C.; Ulgiati, S. A review on circular economy: The expected transition to a balanced interplay of environmental and economic systems. J. Clean. Prod. 2016, 114, 11-32. [CrossRef]

16. Talmar, M.; Walrave, B.; Podoynitsyna, K.S.; Holmström, J.; Romme, A.G.L. Mapping, analyzing and designing innovation ecosystems: The Ecosystem Pie Model. Long Range Plan. 2018. [CrossRef]

17. Tate, W.L.; Bals, L.; Bals, C.; Foerstl, K. Seeing the forest and not the trees: Learning from nature's circular economy. Resour. Conserv. Recycl. 2019, 149, 115-129. [CrossRef]

18. Boer, H.; During, W.E. Innovation, what innovation? a comparison between product, process and organizational innovation. Int. J. Technol. Manag. 2001, 22, 83-107. [CrossRef]

19. Chesbrough, H. Business model innovation: Opportunities and barriers. Long Range Plan. 2010, 43, $354-363$. [CrossRef]

20. Richardson, J. The business model: An integrative framework for strategy execution. Strateg. Chang. 2008, 17, 133-144. [CrossRef]

21. Bocken, N.M.P.; Short, S.W. Towards a sufficiency-driven business model: Experiences and opportunities. Environ. Innov. Soc. Transit. 2016, 18, 41-61. [CrossRef]

22. Jacobides, M.G.; Cennamo, C.; Gawer, A. Towards a theory of ecosystems. Strateg. Manag. J. 2018, 39, 2255-2276. [CrossRef]

23. Rossi, M.; Germani, M.; Zamagni, A. Review of ecodesign methods and tools. Barriers and strategies for an effective implementation in industrial companies. J. Clean. Prod. 2016, 129, 361-373. [CrossRef]

24. Haines-Gadd, M.; Chapman, J.; Lloyd, P.; Mason, J.; Aliakseyeu, D. Emotional durability design Nine-A tool for product longevity. Sustainability 2018, 10, 1948. [CrossRef]

25. Wastling, T.; Charnley, F.; Moreno, M. Design for circular behaviour: Considering users in a circular economy. Sustainability 2018, 10, 1743. [CrossRef]

26. Pieroni, M.P.P.; McAloone, T.C.; Pigosso, D.C.A. Business model innovation for circular economy and sustainability: A review of approaches. J. Clean. Prod. 2019, 215, 198-216. [CrossRef]

27. Bocken, N.; Strupeit, L.; Whalen, K.; Nußholz, J.; Bocken, N.; Strupeit, L.; Whalen, K.; Nußholz, J. A Review and Evaluation of Circular Business Model Innovation Tools. Sustainability 2019, 11, 2210. [CrossRef]

28. Joyce, A.; Paquin, R.L. The triple layered business model canvas: A tool to design more sustainable business models. J. Clean. Prod. 2016, 135, 1474-1486. [CrossRef]

29. Bocken, N.; Schuit, C.S.C.; Kraaijenhagen, C. Experimenting with a circular business model: Lessons from eight cases. Environ. Innov. Soc. Transit. 2018, 28, 79-95. [CrossRef]

30. Nußholz, J.L.K. A circular business model mapping tool for creating value from prolonged product lifetime and closed material loops. J. Clean. Prod. 2018, 197, 185-194. [CrossRef]

31. Bocken, N.M.P.; Short, S.; Rana, P.; Evans, S. A value mapping tool for sustainable business modelling. Corp. Gov. Int. J. Bus. Soc. 2013, 13, 482-497. [CrossRef]

32. Sinclair, M.; Sheldrick, L.; Moreno, M.; Dewberry, E. Consumer intervention mapping-A tool for designing future product strategies within circular product service systems. Sustainability 2018, 10, 2088. [CrossRef]

33. Laasch, O. Beyond the purely commercial business model: Organizational value logics and the heterogeneity of sustainability business models. Long Range Plan. 2018, 51, 158-183. [CrossRef]

34. Stubbs, W.; Cocklin, C. Conceptualizing a "Sustainability Business Model. " Organ. Environ. 2008, 21, 103-127. [CrossRef]

35. Antikainen, M.; Valkokari, K.; Mcclelland, J. A Framework for Sustainable Circular Business Model Innovation. Technol. Innov. Manag. Rev. 2016, 6, 5-12. [CrossRef]

36. Leising, E.; Quist, J.; Bocken, N. Circular Economy in the building sector: Three cases and a collaboration tool. J. Clean. Prod. 2018, 176, 976-989. [CrossRef]

37. Velte, C.J.; Steinhilper, R. Complexity in a Circular Economy: A Need for Rethinking Complexity Management Strategies. In Proceedings of the World Congress on Engineering 2016, London, UK, 29 June-1 July 2016.

38. Bocken, N.M.P.; Boons, F.; Baldassarre, B. Sustainable business model experimentation by understanding ecologies of business models. J. Clean. Prod. 2019, 208, 1498-1512. [CrossRef]

39. Adner, R. Ecosystem as Structure: An Actionable Construct for Strategy. J. Manag. 2016, 43, 39-58. [CrossRef] 
40. Fuller, J.; Jacobides, M.G.; Reeves, M. The Myths and Realities of Business Ecosystems. MIT Sloan Manag. Rev. 2019, 60, 1-9.

41. Van de Ven, A.H. Engaged Scholarship: A Guide for Organizational and Social Research; Oxford University Press: Oxford, UK, 2007; p. 344.

42. Romme, A.G.L.; Reymen, I.M.M.J. Entrepreneurship at the interface of design and science: Toward an inclusive framework. J. Bus. Ventur. Insights 2018, 10, e00094. [CrossRef]

43. Denyer, D.; Tranfield, D.; Van Aken, J.E. Developing design propositions through research synthesis. Organ. Stud. 2008, 29, 393-413. [CrossRef]

44. Tukker, A.; Bulavskaya, T.; Giljum, S.; de Koning, A.; Lutter, S.; Simas, M.; Stadler, K.; Wood, R. Environmental and resource footprints in a global context: Europe's structural deficit in resource endowments. Glob. Environ. Chang. 2016, 40, 171-181. [CrossRef]

45. Brown, P.; Bocken, N.; Balkenende, R.; Brown, P.; Bocken, N.; Balkenende, R. Why Do Companies Pursue Collaborative Circular Oriented Innovation? Sustainability 2019, 11, 635. [CrossRef]

46. Ellen MacArthur Foundation Cities and Circular Economy for Food; Ellen Macarthur Foundation: Cowes, UK, 2018.

47. Adams, R.; Jeanrenaud, S.; Bessant, J.; Denyer, D.; Overy, P. Sustainability-oriented Innovation: A Systematic Review. Int. J. Manag. Rev. 2016, 18, 180-205. [CrossRef]

48. Ceschin, F.; Gaziulusoy, I. Evolution of design for sustainability: From product design to design for system innovations and transitions. Des. Stud. 2016, 47, 118-163. [CrossRef]

49. Flood, R.L. The Relationship of 'Systems Thinking' to Action Research. Syst. Pract. Action Res. 2010, 23, 269-284. [CrossRef]

50. Lewandowski, M. Designing the business models for circular economy-towards the conceptual framework. Sustainability 2016, 8, 43. [CrossRef]

51. Patala, S.; Jalkala, A.; Keränen, J.; Väisänen, S.; Tuominen, V.; Soukka, R. Sustainable value propositions: Framework and implications for technology suppliers. Ind. Mark. Manag. 2016, 59, 144-156. [CrossRef]

52. Magretta, J. Why Business Models Matter. Harv. Bus. Rev. 2002, 80, 86-92.

53. Adner, R. The wide lens: A new strategy for innovation; Penguin UK: London, UK, 2012; ISBN 978-1-59184-460-0.

54. Teece, D.J. Explicating dynamic capabilities: The nature and microfoundations of (sustainable) enterprise performance. Strateg. Manag. J. 2007, 28, 1319-1350. [CrossRef]

55. Stahel, W. The performance economy: Business models for the functional service economy. In Handbook of Performability Engineering; Springer Science \& Business Media: Berlin, Germany, 2008; pp. 127-138. ISBN 978-1-84800-131-2.

56. McDonough, W.; Braungart, M. Remaking the Way We Make Things: Cradle to Cradle; North Point Press: New York, NY, USA, 2002; ISBN 1429973846.

57. Konietzko, J.; Bocken, N.; Hultink, E.J. Online Platforms and the Circular Economy. In Innovation for Sustainability—Business Transformations Towards a Better World; Bocken, N., Ritala, P., Albareda, L., Verburg, R., Eds.; Palgrave: London, UK, 2019.

58. Hens, L.; Block, C.; Cabello-Eras, J.J.; Sagastume-Gutierez, A.; Garcia-Lorenzo, D.; Chamorro, C.; Herrera Mendoza, K.; Haeseldonckx, D.; Vandecasteele, C. On the evolution of "Cleaner Production" as a concept and a practice. J. Clean. Prod. 2018, 172, 3323-3333. [CrossRef]

59. Cardoso, A.C.; Free, G.; Nõges, P.; Kaste, Ø.; Poikane, S.; Solheim, A.L. Lake Management, Criteria. In Encyclopedia of Inland Waters; Elsevier Science: Amsterdam, the Netherlands, 2009; ISBN 978-0-12-370626-3.

60. Pagoropoulos, A. The Emergent Role of Digital Technologies in the Circular Economy: A Review. Procedia CIRP 2017, 64, 19-24. [CrossRef]

61. Kerin, M.; Pham, D.T. A review of emerging industry 4.0 technologies in remanufacturing. J. Clean. Prod. 2019, 237, 117805. [CrossRef]

62. Alcayaga, A.; Wiener, M.; Hansen, E.G. Towards a framework of smart-circular systems: An integrative literature review. J. Clean. Prod. 2019, 221, 622-634. [CrossRef]

63. Ellen MacArthur Foundation, Artificial Intelligence and the Circular Economy; Ellen MacArthur Foundation: Cowes, UK, 2019.

64. Baumann, H.; Boons, F.; Bragd, A. Mapping the green product development field: Engineering, policy and business perspectives. J. Clean. Prod. 2002, 10, 409-425. [CrossRef] 
65. Bocken, N.M.P.; Allwood, J.M.; Willey, A.R.; King, J.M.H. Development of a tool for rapidly assessing the implementation difficulty and emissions benefits of innovations. Technovation 2012, 32, 19-31. [CrossRef]

66. Impossible Foods Home-Impossible Foods. Available online: https://impossiblefoods.com/ (accessed on 6 August 2019).

67. Bocken, N.M.P.; Mugge, R.; Bom, C.A.; Lemstra, H.J. Pay-per-use business models as a driver for sustainable consumption: Evidence from the case of HOMIE. J. Clean. Prod. 2018, 198, 498-510. [CrossRef]

68. Allwood, J.M. Squaring the Circular Economy: The Role of Recycling within a Hierarchy of Material Management Strategies. In Handbook of Recycling: State-of-the-art for Practitioners, Analysts, and Scientists; Newnes: Oxford, UK, 2014; ISBN 9780123965066.

69. Lacy, P.; Keeble, J.; McNamara, R.; Rutqvist, J.; Haglund, T.; Cui, M.; Cooper, A.; Pettersson, C.; Eckerle, K.; Buddemeier, P.; et al. Circular Advantage: Innovative Business Models and Technologies to Create Value in a World without Limits to Growth; Accenture: Chicago, IL, USA, 2014.

70. Peerby. Available online: https://www.peerby.com/beta-dashboard (accessed on 10 November 2019).

71. Cooper, D.R.; Skelton, A.C.H.; Moynihan, M.C.; Allwood, J.M. Component level strategies for exploiting the lifespan of steel in products. Resour. Conserv. Recycl. 2014, 84, 24-34. [CrossRef]

72. Luttropp, C.; Lagerstedt, J. EcoDesign and The Ten Golden Rules: Generic advice for merging environmental aspects into product development. J. Clean. Prod. 2006, 14, 1396-1408. [CrossRef]

73. Den Hollander, M.C.; Bakker, C.A.; Hultink, E.J. Product Design in a Circular Economy: Development of a Typology of Key Concepts and Terms. J. Ind. Ecol. 2017, 21, 517-525. [CrossRef]

74. Tukker, A. Eight types of product-service system: Eight ways to sustainability? Experiences from suspronet. Bus. Strateg. Environ. 2004, 13, 246-260. [CrossRef]

75. Tukker, A. Product services for a resource-efficient and circular economy-A review. J. Clean. Prod. 2015, 97, 76-91. [CrossRef]

76. Linder, M.; Williander, M. Circular Business Model Innovation: Inherent Uncertainties. Bus. Strateg. Environ. 2015, 26, 182-196. [CrossRef]

77. Kjaer, L.L.; Pigosso, D.C.A.; Niero, M.; Bech, N.M.; McAloone, T.C. Product/Service-Systems for a Circular Economy: The Route to Decoupling Economic Growth from Resource Consumption? J. Ind. Ecol. 2019, 23, 22-35. [CrossRef]

78. Mont, O. Clarifying the concept of product-Service system. J. Clean. Prod. 2002, 10, 237-245. [CrossRef]

79. Ellen Macarthur Foundation Kaer Air Conditioning as a Service Reduces Building Carbon Emissions. Available online: https:/www.ellenmacarthurfoundation.org/case-studies/air-conditioning-as-a-servicereduces-building-carbon-emissions (accessed on 27 August 2019).

80. Ellen MacArthur Foundation, Reuse—Rethinking Packaging; Ellen MacArthur Foundation: Cowes, UK, 2019.

81. Haffmans, S.; van Gelder, M.; van Hinte, E.; Zijlstra, Y. Products that Flow: Circular Business Models and Design Strategies for Fast-Moving Consumer Goods; BIS: Amsterdam, the Netherlands, 2018; ISBN 9789063694982.

82. Loop. Loop US. Available online: https://loopstore.com/ (accessed on 6 August 2019).

83. Aquafil Aquafil-The ECONYL®Yarn. Available online: https://www.aquafil.com/sustainability/econyl/ (accessed on 6 August 2019).

84. Ellen MacArthur Foundation Case Studies-Teemill. Available online: https://www. ellenmacarthurfoundation.org/case-studies/an-open-access-circular-supply-chain-for-fashion (accessed on 21 August 2019).

85. Hopper, J.R.; Nielsen, J.M. Recycling as altruistic behavior: Normative and Behavioral Strategies to Expand Participation in a Community Recycling Program. Environ. Behav. 1991, 23, 195-220. [CrossRef]

86. SOOP. Available online: http://www.aworldofsoop.com/ (accessed on 28 August 2019).

87. Scruggs, C.E. Reducing hazardous chemicals in consumer products: Proactive company strategies. J. Clean. Prod. 2013, 44, 105-114. [CrossRef]

88. Cradle to Cradle Resources-Cradle to Cradle Products Innovation Institute. Available online: https: //www.c2ccertified.org/resources/detail/cradle-to-cradle-certified-banned-list-of-chemicals (accessed on 6 August 2019).

89. Byggeth, S.; Broman, G.; Robèrt, K.H. A method for sustainable product development based on a modular system of guiding questions. J. Clean. Prod. 2007, 15, 1-11. [CrossRef]

90. Vestaron. Available online: https://www.vestaron.com/ (accessed on 28 August 2019).

91. Techcrunch Apple Leads Corporate American Solar Energy Usage; TechCrunch: Bay Area, CA, USA, 2019. 
92. Lystek: Leaders in Biosolids and Organics Management. Leaders in Biosolids \& Amp; Organics Management. Available online: https://lystek.com/ (accessed on 30 September 2019).

93. Morlet, A.; Blériot, J.; Opsomer, R.; Linder, M.; Henggeler, A.; Bluhm, A.; Carrera, A. Intelligent Assets: Unlocking the Circular Economy Potential; Ellen MacArthur Foundation: Cowes, UK, 2016; pp. 1-25.

94. Bocken, N.; Ingemarsdotter, E.; Gonzalez, D. Designing Sustainable Business Models: Exploring IoT-Enabled Strategies to Drive Sustainable Consumption. In Sustainable Business Models; Springer International Publishing: Cham, Switzerland, 2019; pp. 61-88.

95. Xu, M.; Cai, H.; Liang, S. Big data and industrial ecology. J. Ind. Ecol. 2015, 19, 205-210. [CrossRef]

96. Nobre, G.C.; Tavares, E. Scientific literature analysis on big data and internet of things applications on circular economy: A bibliometric study. Scientometrics 2017, 111, 463-492. [CrossRef]

97. Hribernik, K.; Ghrairi, Z.; Hans, C.; Thoben, K. Co-creating the Internet of Things-First Experiences in the Participatory Design of Intelligent Products with Arduino. In Proceedings of the 2011 17th International Conference on Concurrent Enterprising, Aachen, Germany, 20-22 June 2011; pp. 1-9.

98. Whim.All Your Journeys with Bus, Tram, Taxi, Car, Bike and More in 1 App. Available online: https: //whimapp.com/ (accessed on 25 September 2019).

99. Bocken, N.M.P.; Short, S.W.; Rana, P.; Evans, S. A literature and practice review to develop sustainable business model archetypes. J. Clean. Prod. 2014, 65, 42-56. [CrossRef]

100. Adams, R.J.; Smart, P.; Huff, A.S. Shades of Grey: Guidelines for Working with the Grey Literature in Systematic Reviews for Management and Organizational Studies. Int. J. Manag. Rev. 2016, 19, 432-454. [CrossRef]

101. Cities in the Circular Economy: An initial Exploration; EMF: Cowes, UK, 2017.

102. Ellen MacArthur Foundation. Towards a Circular Economy-Economic and Business Rationale for an Accelerated Transition. Available online: https://www.greengrowthknowledge.org/resource/towardscircular-economy-economic-and-business-rationale-accelerated-transition (accessed on 16 July 2019).

103. IDEO. The Circular Design Guide. Available online: https://www.circulardesignguide.com/ (accessed on 19 September 2019).

104. ResCom. Product Lifecycle Management And Design for Multiple Lifecycles. Available online: https: //www.rescoms.eu/project (accessed on 19 September 2019).

105. Jarzabkowski, P.; Kaplan, S. Strategy tools-in-use: A framework for understanding "technologies of rationality" in practice. Strateg. Manag. J. 2015, 36, 537-558. [CrossRef]

106. Golembewski, M.; Selby, M. Ideation Decks: A Card Based Ideation Tool. In Proceedings of the DIS '10: 8th ACM Conference on Designing Interactive Systems, Aarhus, Denmark, 16-20 August 2010.

107. Friedman, B.; Hendry, D.G. The envisioning cards: A toolkit for catalyzing humanistic and technical imaginations. In Proceedings of the CHI' 122012 ACM Annual Conference Human Factors Computer Systems, Austin, TX, USA, 5-10 May 2012.

108. Van Aken, J.E.; Romme, G. Reinventing the future: Adding design science to the repertoire of organization and management studies. Organ. Manag. J. 2009, 6, 5-12. [CrossRef]

109. Peffers, K.; Tuunanen, T.; Rothenberger, M.A.; Chatterjee, S. A Design Science Research Methodology for Information Systems Research. J. Manag. Inf. Syst. 2007, 24, 45-77. [CrossRef]

110. Geissdoerfer, M.; Bocken, N.; Hultink, E.J. Design Thinking to Enhance the Sustainable Business Modelling Process. J. Clean. Prod. 2016, 135, 1218-1232. [CrossRef]

111. Baldassarre, B.; Calabretta, G.; Bocken, N.M.P.; Jaskiewicz, T. Bridging sustainable business model innovation and user-driven innovation: A process for sustainable value proposition design. J. Clean. Prod. 2017, 147, 175-186. [CrossRef]

112. Guldmann, E.; Bocken, N.M.P.; Brezet, H. A Design Thinking Framework for Circular Business Model Innovation. J. Bus. Model. 2019, 7, 39-70.

113. Davis, F.D. Perceived Usefulness, Perceived Ease Of Use, And User Acceptance of Information Technology. MIS Q. 1989, 13, 319-340. [CrossRef]

114. Tukker, A.; Emmert, S.; Charter, M.; Vezzoli, C.; Sto, E.; Munch Andersen, M.; Geerken, T.; Tischner, U.; Lahlou, S. Fostering change to sustainable consumption and production: An evidence based view. J. Clean. Prod. 2008, 16, 1218-1225. [CrossRef] 
115. Bocken, N.M.P.; Allwood, J.M.; Willey, A.R.; King, J.M.H. Development of an eco-ideation tool to identify stepwise greenhouse gas emissions reduction options for consumer goods. J. Clean. Prod. 2011, 19, 1279-1287. [CrossRef]

116. Studio Davero Studio Davero. Puzzle Peace. Available online: http://studiodavero.nl/portfolio_page/puzzlepeace/ (accessed on 6 August 2019).

117. Shahbazi, S.; Wiktorsson, M.; Kurdve, M.; Jönsson, C.; Bjelkemyr, M. Material efficiency in manufacturing: Swedish evidence on potential, barriers and strategies. J. Clean. Prod. 2016, 127, 438-450. [CrossRef]

118. Nissen, U. A methodology for the development of cleaner products. The ideal-eco-product approach. J. Clean. Prod. 1995, 3, 83-87. [CrossRef]

119. Heyes, G.; Sharmina, M.; Mendoza, J.M.F.; Gallego-Schmid, A.; Azapagic, A. Developing and implementing circular economy business models in service-oriented technology companies. J. Clean. Prod. 2018, 177, 621-632. [CrossRef]

120. Rytle RYTLE—The Smart Move-THE SMART MOVE. Available online: https://rytle.de/?lang=en (accessed on 26 September 2019).

121. Dig Inn. Available online: https://www.diginn.com/ (accessed on 27 August 2019).

122. Planing, P. Towards a circular economy-How business model innovation will help to make the shift. Int. J. Bus. Glob. 2018, 20, 71-83. [CrossRef]

123. Street, G. Home-Gerrard Street. Available online: https://gerrardstreet.nl/ (accessed on 26 September 2019).

124. Pialot, O.; Millet, D.; Bisiaux, J. “Upgradable PSS": Clarifying a new concept of sustainable consumption/production based on upgradablility. J. Clean. Prod. 2017, 141, 538-550. [CrossRef]

125. Chierici, E.; Copani, G. Remanufacturing with Upgrade PSS for New Sustainable Business Models. Procedia CIRP 2016, 47, 531-536. [CrossRef]

126. Fairphone. Available online: https://www.fairphone.com/en/ (accessed on 21 August 2019).

127. Ellen MacArthur Foundation Case Studies. Available online: https://www.ellenmacarthurfoundation.org/ case-studies/remanufacturing-at-scale (accessed on 7 August 2019).

128. Gispen Remade by Gispen. Circular Economy. About Remade. Gispen. Available online: https://www.gispen. com/en/circular-economy/repurpose-remade-by-gispen (accessed on 19 August 2019).

129. Bosch, T.; Verploegen, K.; Grösser, S.N.; van Rhijn, G. Sustainable furniture that grows with end-users. In Dynamics of Long-Life Assets: From Technology Adaptation to Upgrading the Business Model; Springer: New York, NY, USA, 2017; ISBN 9783319454382.

130. Darn Tough Vermont Darn Tough Vermont_Premium Merino Wool Socks, for more than Hiking. Available online: https://darntough.com/ (accessed on 6 August 2019).

131. Nudie Jeans Free Repairs for Life-Nudie Jeans. Available online: https://www.nudiejeans.com/page/freerepairs-for-life (accessed on 26 September 2019).

132. Khan, M.A.; Mittal, S.; West, S.; Wuest, T. Review on upgradability-A product lifetime extension strategy in the context of product service systems. J. Clean. Prod. 2018, 204, 1154-1168. [CrossRef]

133. Linder, M.; Sarasini, S.; van Loon, P. A Metric for Quantifying Product-Level Circularity. J. Ind. Ecol. 2017, 21, 545-558. [CrossRef]

134. Krikke, H.; Le Blanc, I.; Van De Velde, S. Product modularity and the design of closed-loop supply chains. Calif. Manage. Rev. 2004, 46, 23-39. [CrossRef]

135. SPC. Design for Recycled Content Guide. Available online: https://recycledcontent.org/ (accessed on 26 September 2019).

136. Singh, J.; Ordoñez, I. Resource recovery from post-consumer waste: Important lessons for the upcoming circular economy. J. Clean. Prod. 2016, 134, 342-353. [CrossRef]

137. Adidas Adidas Unlocks a Circular Future for Sports with Futurecraft.loop: A Performance Running Shoe Made to be Remade. Available online: https://news.adidas.com/running/adidas-unlocks-a-circularfuture-for-sports-with-futurecraft.loop--a-performance-running-shoe-made-t/s/c2c22316-0c3e-4e7b-8c32408ad3178865 (accessed on 6 August 2019).

138. Kent, R.; Kent, R. Design quality management. Qual. Manag. Plast. Process. 2016, 227-262. [CrossRef]

139. Magnomer. Available online: https://www.magnomer.com/ (accessed on 26 September 2019).

140. Roetz ROETZ—Configure your Own Unique (e)-Bike. Available online: https://roetz-bikes.com/ (accessed on 6 August 2019). 
141. Closing the Loop Closed loop Solutions for Mobile Phones. Closing the Loop. Available online: http: //www.closingtheloop.eu/ (accessed on 6 August 2019).

142. Herczeg, G.; Akkerman, R.; Hauschild, M.Z. Supply chain collaboration in industrial symbiosis networks. J. Clean. Prod. 2018, 171, 1058-1067. [CrossRef]

143. Swilling, M.; Hajer, M.; Baynes, T.; Bergesen, J.; Labbé, F.; Musango, J.K.; Ramaswami, A.; Robinson, B.; Salat, S.; Suh, S.; et al. The Weight of Cities: Resource Requirements of Future Urbanization; UN Environment Programme: Nairobi, Kenya, 2018.

144. Sono Motors Invest-Sono Motors. Available online: https://sonomotors.com/en/invest/? (accessed on 26 September 2019).

145. Ecovative Ecovative Design. Available online: https://ecovativedesign.com/ (accessed on 8 December 2019).

146. Berkel, R.; Willems, E.; Lafleur, M. The Relationship between Cleaner Production and Industrial Ecology. J. Ind. Ecol. 1997, 1, 51-66. [CrossRef]

147. Foodlogica FOODLOGICA—DUURZAME LOGISTIEK VOOR LOKALE MERKEN EN HORECA. Available online: https://foodlogica.com/ (accessed on 6 August 2019).

148. Waka Waka WakaWakaß_Premium Portable Solar Products, for Everyone. Available online: https: //waka-waka.com/en/ (accessed on 26 September 2019).

149. SolarRoadways Home-SolarRoadways. Available online: http://www.solarroadways.com/ (accessed on 6 August 2019).

150. The Ocean Cleanup The Ocean Cleanup. Available online: https://theoceancleanup.com/ (accessed on 6 August 2019).

151. Forister, M.L.; Pelton, E.M.; Black, S.H. Declines in insect abundance and diversity: We know enough to act now. Conserv. Sci. Pract. 2019. [CrossRef]

152. Häagen-Dazs Häagen-Dazs@Loves Honey Bees. Häagen-Dazs®. Available online: https://www.haagendazs. us/about/news/haagen-dazsr-loves-honey-bees (accessed on 6 August 2019).

153. European Commission Accelerated Metallurgy Project Website. Available online: https://cordis.europa.eu/ project/rcn/99430/factsheet/en (accessed on 26 May 2019).

154. Manninen, K.; Koskela, S.; Antikainen, R.; Bocken, N.; Dahlbo, H.; Aminoff, A. Do circular economy business models capture intended environmental value propositions? J. Clean. Prod. 2018, 171, 413-422. [CrossRef]

155. Barile, S.; Lusch, R.; Reynoso, J.; Saviano, M.; Spohrer, J. Systems, networks, and ecosystems in service research. J. Serv. Manag. 2016, 27, 652-674. [CrossRef]

156. Främling, K.; Holmström, J.; Loukkola, J.; Nyman, J.; Kaustell, A. Sustainable PLM through Intelligent Products. Eng. Appl. Artif. Intell. 2013, 26, 789-799. [CrossRef]

157. Lopes de Sousa Jabbour, A.B.; Jabbour, C.J.C.; Godinho Filho, M.; Roubaud, D. Industry 4.0 and the circular economy: A proposed research agenda and original roadmap for sustainable operations. Ann. Oper. Res. 2018, 270, 273-286. [CrossRef]

158. Gupta, S.; Chen, H.; Hazen, B.T.; Kaur, S.; Santibañez Gonzalez, E.D.R. Circular economy and big data analytics: A stakeholder perspective. Technol. Forecast. Soc. Chang. 2019, 144, 466-474. [CrossRef]

159. Nascimento, D.L.M.; Alencastro, V.; Quelhas, O.L.G.; Caiado, R.G.G.; Garza-Reyes, J.A.; Lona, L.R.; Tortorella, G. Exploring Industry 4.0 technologies to enable circular economy practices in a manufacturing context: A business model proposal. J. Manuf. Technol. Manag. 2019, 30, 607-627. [CrossRef]

160. Ge, X.; Jackson, J. The Big Data Application Strategy for Cost Reduction in Automotive Industry. SAE Int. J. Commer. Veh. 2014, 7, 588-598. [CrossRef]

161. Luscuere, L. Materials Passports: Providing Insights in the Circularity of Materials, Products and Systems-Lars Luscuere. In Proceedings of the Sustainable Innovation 2016, Surrey, UK, 7-8 November 2016; pp. 176-179.

162. Jabbour, C.J.C.; Jabbour, A.B.L. de S.; Sarkis, J.; Filho, M.G. Unlocking the circular economy through new business models based on large-scale data: An integrative framework and research agenda. Technol. Forecast. Soc. Chang. 2019, 144, 546-552. [CrossRef]

163. Launchforth launchforth Website. Available online: https://launchforth.io/ (accessed on 26 September 2019).

164. ZenRobotics. Leader in Robotic Waste Separation. Available online: https://zenrobotics.com/ (accessed on 26 September 2019).

165. Frenken, K.; Schor, J. Putting the sharing economy into perspective. Environ. Innov. Soc. Transit. 2017, 23, 3-10. [CrossRef] 
166. Guzzo, D.; Trevisan, A.H.; Echeveste, M.; Costa, J.M.H. Circular Innovation Framework: Verifying Conceptual to Practical Decisions in Sustainability-Oriented Product-Service System Cases. Sustainability 2019, 11, 3248. [CrossRef]

167. Blomsma, F.; Pieroni, M.; Kravchenko, M.; Pigosso, D.C.A.; Hildenbrand, J.; Kristinsdottir, A.R.; Kristoffersen, E.; Shahbazi, S.; Nielsen, K.D.; Jönbrink, A.-K.; et al. Developing a circular strategies framework for manufacturing companies to support circular economy-oriented innovation. J. Clean. Prod. 2019, 241, 118271. [CrossRef]

168. Niero, M.; Negrelli, A.J.; Hoffmeyer, S.B.; Olsen, S.I.; Birkved, M. Closing the loop for aluminum cans: Life Cycle Assessment of progression in Cradle-to-Cradle certification levels. J. Clean. Prod. 2016, 126, 352-362. [CrossRef]

169. Rittel, H.W.J.; Webber, M.M. Dilemmas in a general theory of planning. Policy Sci. 1973, 4, 155-169. [CrossRef]

170. Moreau, V.; Sahakian, M.; van Griethuysen, P.; Vuille, F. Coming Full Circle: Why Social and Institutional Dimensions Matter for the Circular Economy. J. Ind. Ecol. 2017, 21, 497-506. [CrossRef]

171. Van Berkel, R.; Willems, E.; Lafleur, M. Development of an industrial ecology toolbox for the introduction of industrial ecology in enterprises-I. J. Clean. Prod. 1997, 5, 11-25. [CrossRef]

172. Allwood, J.M.; Cullen, J.M.; Milford, R.L. Options for achieving a 50\% cut in industrial carbon emissions by 2050. Environ. Sci. Technol. 2010, 44, 1888-1894. [CrossRef]

173. Moreno, M.; de los Rios, C.; Charnley, F. Guidelines for Circular Design: A Conceptual Framework. Sustainability 2016, 8, 937. [CrossRef]

174. Nižetić, S.; Djilali, N.; Papadopoulos, A.; Rodrigues, J.J.P.C. Smart technologies for promotion of energy efficiency, utilization of sustainable resources and waste management. J. Clean. Prod. 2019, 231, 565-591. [CrossRef]

(C) 2020 by the authors. Licensee MDPI, Basel, Switzerland. This article is an open access article distributed under the terms and conditions of the Creative Commons Attribution (CC BY) license (http://creativecommons.org/licenses/by/4.0/). 